Natália Gonczarowska

Efeitos da modulação do sistema endocanabinoide na interação social e extinção da memória aversiva em macacos-prego

(Sapajus spp) 


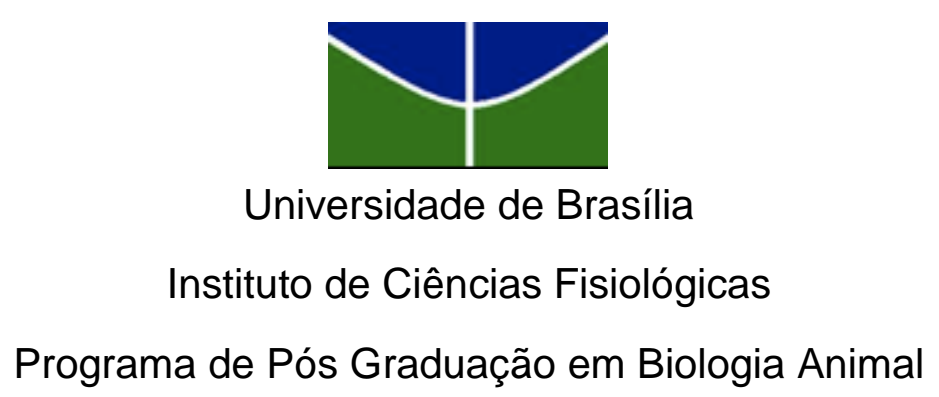

Natália Gonczarowska

\section{Efeitos da modulação do sistema endocanabinoide na interação social e extinção da memória aversiva em macacos-prego (Sapajus spp)}

Dissertação apresentada como requisito para a obtenção do Grau de Mestre em Biologia Animal pelo Programa de Pós Graduação em Biologia Animal da Universidade de Brasília.

Orientador: Prof. Dr. Rafael Plakoudi Souto Maior

Brasília, DF 
Dedico este trabalho ao meu pai, a minha mãe e a minha irmã. 


\section{AGRADECIMENTOS}

Agradeço primeiramente ao meu orientador Prof. Dr. Rafael Plakoudi Souto Maior pela confiança depositada em mim para realização deste trabalho. Obrigada pela paciente orientação, pelos ensinamentos e por todo apoio durante esses dois anos.

Ao Prof. Dr. Carlos Alberto Bezerra Tomaz pelas sugestões e contribuições ao trabalho e pelo grande exemplo profissional.

Ao Prof. Dr. Renato Malcher, que sempre se mostrou disposto a me ajudar. Agradeço por todo material disponibilizado, pelas ideias e discussões sobre o trabalho.

À Prof. Dra. Maria Clotilde Tavares pela preocupação com o bem-estar dos animais, e pela importante contribuição no meu projeto de qualificação. À Prof. Dra. Marília Barros por todas as excelentes sugestões e críticas no meu projeto de qualificação.

À Mariana Jacobsen por dividir comigo momentos de alegrias e incertezas durante essa trajetória. À Patrícia Saletti por estar sempre disposta a me ajudar, por ouvir minhas reclamações e por todas as dicas e sugestões. À Renata Duarte, que me inseriu no Laboratório de Neurociências e Comportamento ainda na graduação, e a quem devo grande parte da minha paixão por essa área. À Ana Garcia, pela agradável companhia e interesse pelo trabalho.

Aos meus outros colegas do Laboratório de Neurociências e Comportamento que me fizeram companhia durante o mestrado: Soraya Lage, Edward Sarmiento, Lía Garrido, e principalmente à Rosângela Rodrigues (obrigada pelas discussões sobre comportamento dos macacos-prego e dicas nas análises dos dados). Ao Lucas Pereira pela disponibilidade para me ajudar, pela humildade e otimismo sempre. 
Ao Programa de Pós Graduação em Biologia Animal.

À Capes e ao Cnpq pelo apoio financeiro.

Aos tratadores, Geinaldo da Silva e Almir Araújo, e aos veterinários Raimundo de Oliveira, Cecília Azevedo e Antonizete dos Reis Souza, pelo cuidado com os animais e por toda ajuda e boa vontade durante os experimentos.

Aos alunos de graduação Patryck Dougllas, Wesley Medeiros, Patrícia Sardote, Fernanda Silveira, Fernando Magela, Isabela Oliveira, Maria Varela e Helena Schuch por toda ajuda na coleta de dados.

Aos meus pais, Sonia e Rubim, por todo amor e incentivo constante, pela dedicação, e pelo exemplo de bondade e generosidade. À minha irmã, Alice, cujos passos tenho seguido desde o nascimento e a quem agradeço pela amizade, carinho e paciência, especialmente nesses últimos meses. Vocês são meu porto seguro!

Ao meu noivo, Arthur, que me incentivou desde o início a ingressar no mestrado. Obrigada pelo amor, por me fazer olhar sempre o lado bom das coisas e pelas horas dedicadas a me explicar estatística. Eu te amo!

A todos meus familiares, em especial meu primo Humberto, pelo companheirismo e amizade.

Ao meu querido amigo Danilo Augusto da Silva de Farias pelos almoços de desabafo e risadas, pela companhia virtual durante muitas madrugadas e pelo apoio em cada etapa da minha graduação e do mestrado. À minha amiga Juliana de Oliveira, sempre doce e alto astral, e que consegue me acalmar com um simples sorriso no rosto. A todas minhas amigas da UnB, pelos diversos momentos divertidos e pelo incentivo constante. 
À minha amiga, Marina de Andrade, que mesmo longe fisicamente consegue se fazer presente em vários momentos da minha vida. Obrigada pela positividade e por sempre torcer por mim. Às minhas outras amigas de Viçosa, agradeço pelo interesse ao meu trabalho e pela torcida nesses dois anos.

A Deus por ter me dado forças para enfrentar todas as dificuldades.

Ao Zoológico de Brasília por conceder a serpente para o estudo. Agradeço especialmente ao Alberto Brito, por toda a ajuda e pelas palavras de otimismo.

Ao Sr. Alexis Souto Maior pela paciência na confecção do aparato experimental e pela simpatia de sempre.

Aos meus sujeitos experimentais e à serpente pela participação no trabalho. A vocês todo meu carinho e respeito.

Aos meus amados Hulk, Malu, Margareth, Sarita e Julieta pela alegria diária e amor incondicional. 
"Embora ninguém possa voltar atrás e fazer um novo começo, qualquer um pode começar agora e fazer um novo fim."

Francisco Cândido Xavier 


\section{RESUMO}

O Sistema Endocanabinoide (SE) é um importante modulador em diferentes funções neurais, incluindo a memória e as emoções. Sabe-se que alterações no funcionamento deste sistema estão envolvidas em várias desordens neurológicas, como os transtornos do espectro do autismo (TEA). Disfunções na interação social e na extinção de memória aversiva são duas das manifestações características de humanos com TEA. Nesse sentido, o presente estudo avaliou o papel do SE na interação social e extinção de memória aversiva em Sapajus spp a partir do bloqueio do receptor CB1 pelo seu antagonista AM 251. O trabalho foi dividido em dois estudos. No primeiro, foram observados os comportamentos sociais e não-sociais de cinco machos após administração de AM 251 nas doses de 3,0, 1,0 e 0,3 mg/kg, i.m. e da solução veículo. Observou-se uma tendência à diminuição de comportamentos sociais na maior dose, corroborando estudos realizados em roedores, que indicam o papel importante do receptor CB1 na interação social dos indivíduos. Os comportamentos de vigilância e locomoção não foram alterados. No segundo estudo, oito macacos-prego foram divididos em dois grupos: controle e AM 251. Estes animais foram encaminhados a um viveiro de testes, onde tinham acesso a uma "caixa-surpresa". Os sujeitos passaram por três etapas experimentais. A primeira consistiu em sessões de habituação, para que cada animal aprendesse a encontrar alimento dentro da caixa. Na segunda, os animais foram tratados com veículo ou AM 251 (3,0 mg/kg, i.m.) 30 minutos antes da sessão. Nesta sessão os sujeitos foram mantidos na "caixa-surpresa" próximos à uma serpente viva por 5 segundos. A terceira etapa consistiu em 5 sessões, idênticas à primeira, e foi medida a latência de retorno dos animais à "caixa-surpresa". Não foi observada diferença significativa entre os grupos para latência de retorno à caixa. Estes resultados sugerem que o AM 251 não alterou o processo de extinção da memória aversiva. O protocolo utilizado neste estudo apresentou um potencial como método de avaliação de extinção de memória aversiva em macacos-prego. Em conjunto, os resultados indicam que o receptor CB1 pode participar da modulação de comportamentos sociais.

Palavras-chave: Receptor CB1; AM 251; Interação social; Extinção de memória aversiva; Macaco-prego. 


\begin{abstract}
The Endocannabinoid System (ES) is an important modulator of different neural functions, including memory and emotions. Changes in the ES's activity is known to play a role in several neurological disorders, such as autism spectrum disorders (ASD). Impairment of social interactions and in aversive memory extinction are two of the many symptoms of humans with ASD. In this sense, this study evaluated the ES's role in social interaction and aversive memory extinction in Sapajus spp by blocking the CB1 receptor with the antagonist AM 251. This work was divided into two studies. In the first study, we observed the social and non-social behaviors of five males after AM 251 administration at the doses of 3,0, 1,0 and 0,3 $\mathrm{mg} / \mathrm{kg}$, i.m. and vehicle. Social behavior tended to decrease at the dose of $3,0 \mathrm{mg} / \mathrm{kg}$, corroborating studies in rodents that indicated an important role of the $\mathrm{CB} 1$ receptor in the social interaction of the subjects. No changes were observed in vigilance and locomotion. In the second study, eight capuchin monkeys were divided in two groups: control and AM 251. These animals were sent to a test cage, where they had access to a "surprise box", during three experimental stages. The first one consisted in habituation sessions where subjects learnt to find food inside the box. In the second stage, the animals were treated with vehicle or AM 251 (3,0 mg/kg, i.m.) 30 minutes before the session. In this session, the subjects were kept inside the "surprise box" in close proximity to a live snake for 5 seconds. The third stage consisted of five sessions, identical to the first, and was measured latency to return to the "surprise box" was measured. There was no significant difference between the groups in terms of the return latency. These results suggest that AM 251 did not change aversive memory extinction. The protocol used in this study is a potentially method to evaluate aversive memory extinction in capuchin monkeys. Taken together, the results indicate that the CB1 receptor may participate in the modulation of social behaviors.
\end{abstract}

Keywords: CB1 Receptor; AM 251; Social interaction; Aversive memory extinction; Capuchin monkeys. 


\section{LISTA DE ABREVIATURAS E SIGLAS}

SE - Sistema Endocanabinoide

CB1 - Receptor canabinoide tipo 1

CB2 - Receptor canabinoide tipo 2

2-AG - 2-aracdonoilglicerol

AEA - Anandamida

TEA - Transtornos do Espectro do Autismo

SNC - Sistema Nervoso Central

$\mathrm{CP}$ - Centro de Primatologia

FAL - Fazenda Água Limpa

IBAMA - Instituto Brasileiro do Meio Ambiente e dos Recursos Naturais Renováveis

CEUA - Comissão de Ética no Uso Animal

CONCEA - Conselho Nacional do Controle de Experimentação Animal 


\section{LISTA DE FIGURAS}

Figura 1. Representação esquemática do SE.

Figura 2. Regiões cerebrais envolvidas na memória aversiva: córtex préfrontal, amígdala e hipocampo. 10

Figura 3. Fotografia do macaco-prego adulto (Sapajus spp) em seu habitat natural.

Figura 4. Pavilhão Central dos Sapajus spp.

Figura 5. Média do tempo de locomoção das sessões experimentais $( \pm$ E.P.M.), em segundos. $n=5$

Figura 6. Média do tempo de vigilância das sessões experimentais ( \pm E.P.M.), em segundos. $n=5$. 20

Figura 7. Média da frequência de comportamentos autodirigidos das sessões experimentais ( \pm E.P.M.), em segundos. $n=5$.

Figura 8. Média do tempo de forrageio das sessões experimentais ( \pm E.P.M.), em segundos. $n=5$.

Figura 9. Média do tempo de interação social das sessões experimentais $( \pm$ E.P.M.), em segundos. $n=5$.

Figura 10. Viveiro de testes. 31

Figura 11. "Caixa-surpresa". 32

Figura 12. Etapa Confronto. 34

Figura 13. Média do tempo de latência de entrada na caixa ( \pm E.P.M) em todas as etapas experimentais, em segundos. 35 


\section{LISTA DE TABELAS}

Tabela 1. Média (erro padrão) do tempo de comportamentos espontâneos nãosociais observados nos cinco machos de Sapajus spp para cada sessão.. .... 21

Tabela 2. Média (erro padrão) do tempo de dois comportamentos espontâneos sociais observados nos cinco machos de Sapajus spp para cada sessão.. .... 22 


\section{SUMÁRIO}

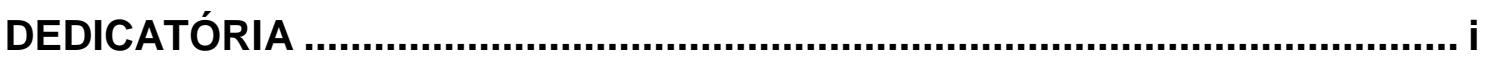

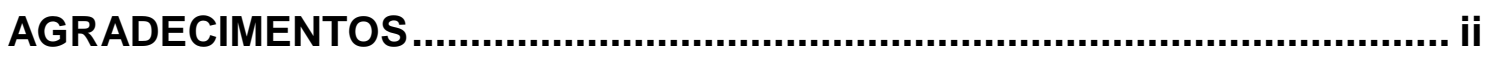

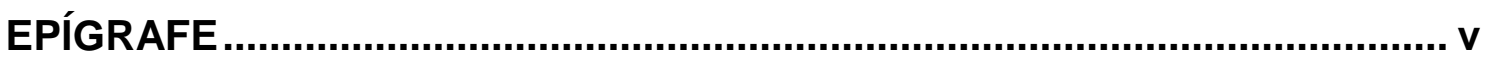

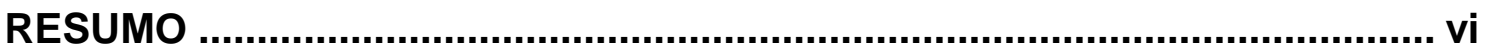

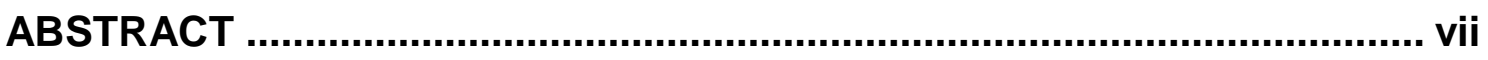

LISTA DE ABREVIATURAS E SIGLAS ................................................... viii

LISTA DE FIGURAS .................................................................................... ix

LISTA DE TABELAS

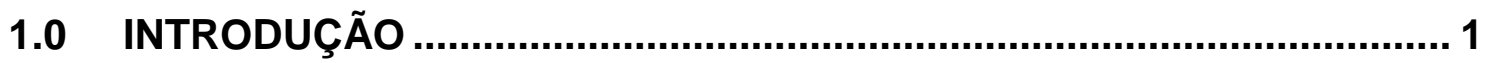

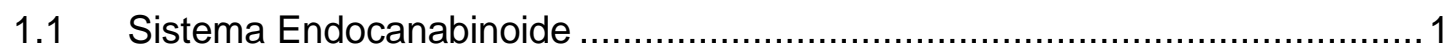

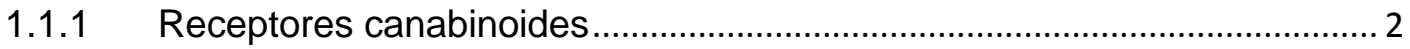

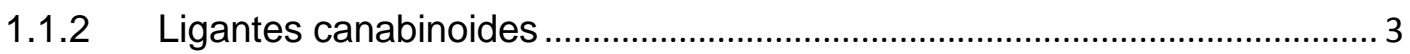

1.2 Transtornos do Espectro do Autismo (TEA) …........................................ 5

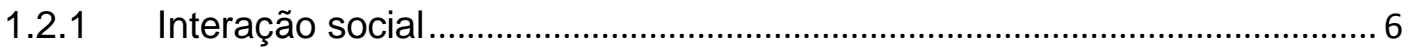

1.2.2 Extinção de memória aversiva ................................................................... 8

1.3 Uso de primatas em pesquisas ............................................................. 10

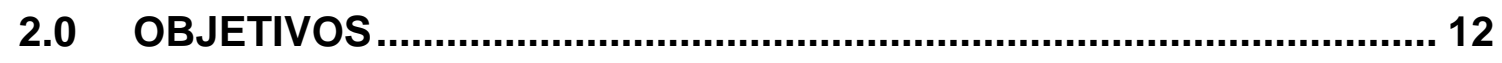

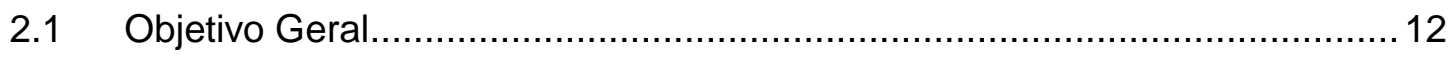

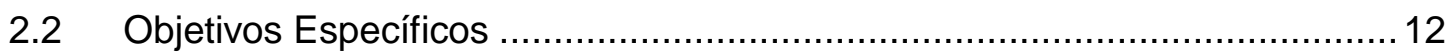

3.0 MATERIAIS E MÉTODO - ESTUDO 1 ................................................ 13

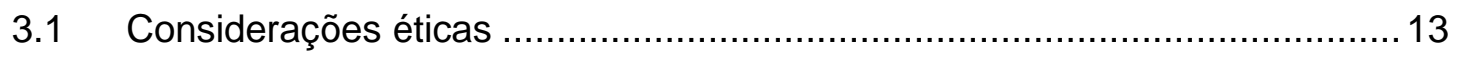

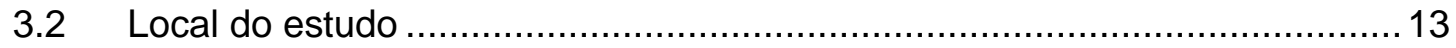

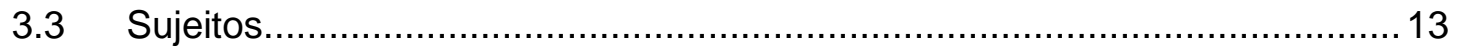

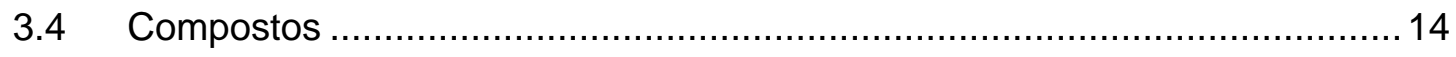

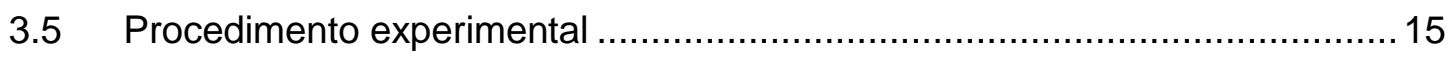


3.6 Análise de dados

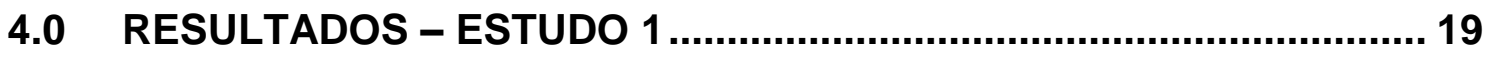

4.1 Comportamentos espontâneos não-sociais ............................................. 19

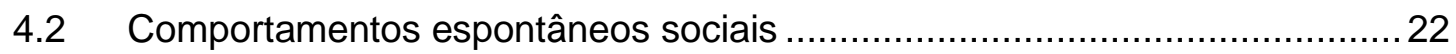

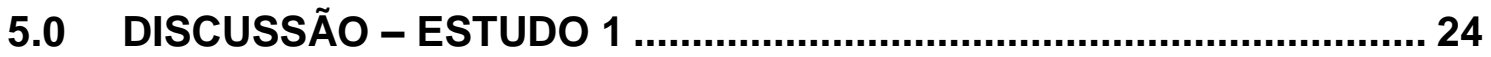

5.1 Comportamentos espontâneos não-sociais .............................................. 24

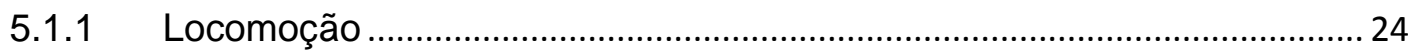

5.1.2 Vigilância e comportamentos autodirigidos ............................................... 25

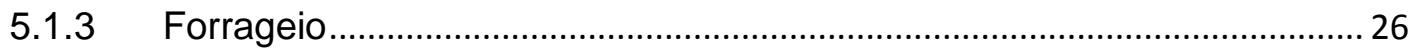

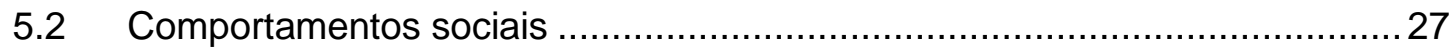

6.0 MATERIAIS E MÉTODO - ESTUDO 2 ............................................ 30

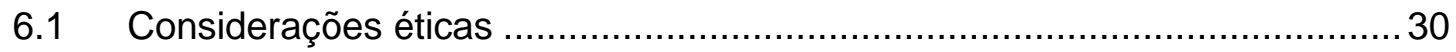

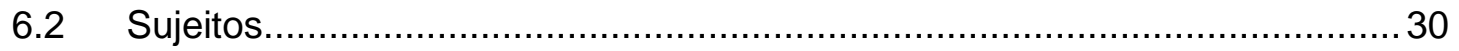

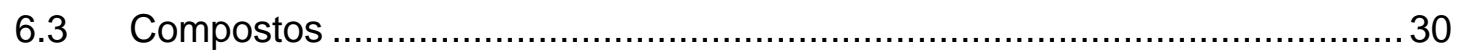

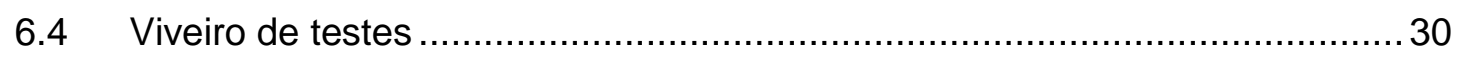

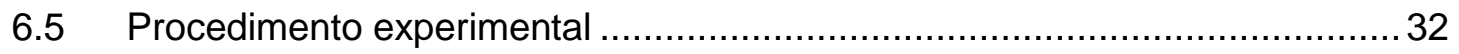

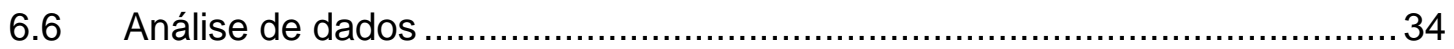

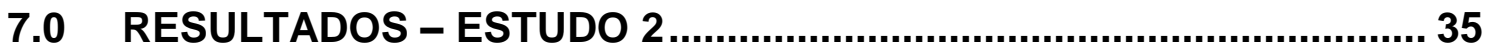

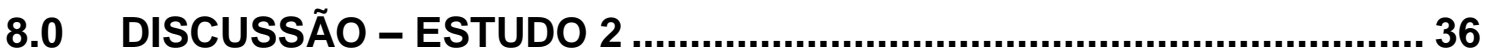

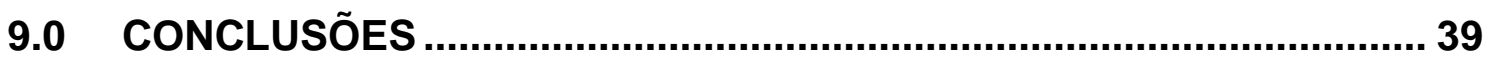

REFERÊNCIAS BIBLIOGRÁFICAS ...................................................... 40

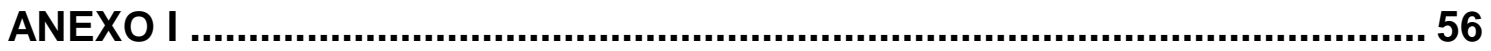

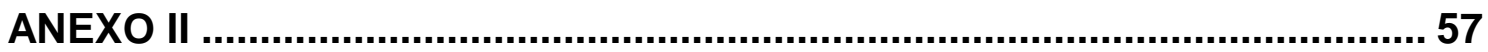




\subsection{INTRODUÇÃO}

\subsection{Sistema Endocanabinoide}

A planta Cannabis spp, popularmente conhecida como maconha, é cultivada há séculos devido às suas propriedades medicinais e psicoativas (Costa et al., 2011). Possivelmente originária da Ásia, acredita-se que tenha se difundido pelo mundo por meio de atividades comerciais e de fluxos migratórios de nômades (Malcher-Lopez \& Ribeiro, 2007; Saito et al., 2010). As flores e folhas dessa planta secretam uma resina que contém compostos psicoativos, chamados de canabinoides (Malcher-Lopez \& Ribeiro, 2007). Atualmente, a Cannabis é a droga ilícita mais consumida no mundo, estimando-se os seus consumidores em $4 \%$ da população mundial adulta (Costa et al., 2011).

$\mathrm{Em}$ relação às suas propriedades medicinais, os canabinoides foram utilizados como analgésicos durante séculos, auxiliando em tratamentos para dor. Além disso, eram também usados como anestésicos cirúrgicos e para tratar casos de epilepsia (Abel, 1980; Elphick \& Egertova, 2001; MalcherLopez, 2014). Em 1930, foi proibido o uso de canabinoides como agentes terapêuticos, por razões políticas e farmacológicas, tais como a instabilidade dos extratos da Cannabis, sua absorção imprevisível e sua insolubilidade em água (Malcher-Lopez \& Ribeiro, 2007).

Atualmente, são conhecidos 538 componentes da Cannabis spp (Costa et al., 2011). Entre eles, os mais abundantes são $\Delta^{9}$-tetra-hidrocanabinol (THC), canabidiol, canabinol, canabigerol e canabicromeno (Mechoulam \& Hanus, 2000). Com a descoberta do composto THC, foi possível identificar receptores para canabinoides no Sistema Nervoso Central e Periférico, e posteriormente, foram encontrados ligantes endógenos para esses receptores (Devane et al., 1992). A partir daí, foi-se designado o Sistema Endocanabinoide.

O Sistema Endocanabinoide (SE) é um importante modulador em diferentes funções neurais. É formado por receptores canabinoides, seus ligantes endógenos e enzimas que participam da produção e degradação dos endocanabinoides (De Petrocellis \& Di Marzo, 2009). Esse sistema está envolvido em diferentes processos fisiológicos, incluindo a memória e o 
aprendizado (Arenos et al., 2006), a modulação de dor (Calignano et al., 1998), o apetite (Kirkham \& Williams, 2001) e as emoções (Bambico et al., 2010).

A descoberta desse sistema, que está ligado direta ou indiretamente a diversos aspectos da fisiologia e homeostase, tem permitido novas pesquisas sobre o tema e uma nova visão sobre as propriedades da Cannabis.

\subsubsection{Receptores canabinoides}

Já foram identificados e descritos pelo menos dois tipos de receptores do sistema endocanabinoide: receptor canabinoide tipo 1 (CB1) e receptor canabinoide tipo 2 (CB2) (Howllet et al., 2002). Tais receptores pertencem à superfamília dos receptores acoplados à proteína $\mathrm{G}$, um dos mais abundantes no Sistema Nervoso Central (SNC) humano, com sete domínios transmembranares (Costa et al., 2011).

Os primeiros estudos relacionados à distribuição regional dos receptores CB1 estabeleceram conceitos fundamentais, como a alta densidade de receptores, o padrão regional característico e a similaridade entre as espécies, que explicam a importância fisiológica e patológica do SE (Herkenham et al., 1990; Herkenham et al., 1991b).

Sabe-se que os receptores CB1 estão presentes em áreas associadas ao controle motor, resposta emocional, memória, comportamentos orientados por objetivos, homeostase energética e funções cognitivas (Breivogel \& SimSelley, 2009; Kano et al., 2009). Em geral, foi demonstrada uma alta densidade desses receptores no bulbo olfatório, formação hipocampal, estriado lateral, globo pálido, substância negra e cerebelo; densidade moderada em áreas do córtex cerebral (especialmente no lobo frontal e parietal e giro do cíngulo), septo, complexo amigdaloide, hipotálamo e na medula espinhal (Chevaleyre et al., 2006; Svíženská et al., 2008). Por outro lado, em órgãos e tecidos periféricos, sua expressão é baixa (Costa et al., 2011). Os receptores CB2 são expressos, sobretudo, no sistema imunológico (Svíženská et al., 2008).

Pode-se considerar que a densidade de receptores canabinoides no SNC atinge níveis comparáveis aos encontrados para receptores glutamatérgicos e GABAérgicos em todo o cérebro (Herkenham et al., 1991a). Além disso, são encontrados tanto em neurônios excitatórios quanto inibitórios, 
o que indica uma participação crucial do SE na regulação da neurotransmissão sináptica (Malcher-Lopez, 2014).

\subsubsection{Ligantes canabinoides}

A descoberta da existência de receptores para canabinoides levou à busca de ligantes produzidos pelo próprio corpo, os endocanabinoides, que são os neuromoduladores endógenos do SE.

O primeiro endocanabinoide encontrado foi a $\mathrm{N}$-aracdonoiletanolamida (Devane et al., 1992), batizada como anandamida (AEA), que significa "êxtase, felicidade ou extrema alegria" (Childers \& Breivogel, 1998). Em seguida, foi descoberto o 2-aracdonoilglicerol (2-AG), ligante mais abundante do SE (Kendall \& Stephen, 2009). Essas moléculas são derivadas da degradação do ácido araquidônico, que são formadas por vias dependentes de fosfolipídeos e liberadas na fenda sináptica por meio de difusão, e se ligam aos receptores canabinoides (De Fonseca et al., 2005).

O modo de ação dos endocanabinoides se diferencia dos neurotransmissores clássicos, tornando-os mensageiros atípicos. Os neurotransmissores são sintetizados nos terminais pré-sinápticos, a partir de precursores específicos, e armazenados em vesículas; ao passo que os endocanabinoides medeiam a transferência de informações dos terminais pós aos pré-sinápticos de uma forma retrógrada (Saito et al., 2010). Ou seja, esses mensageiros são sintetizados sob demanda. Além disso, não são armazenados em vesículas. A sua síntese ocorre em neurônios pós-sinápticos após um influxo de cálcio e ativação de fosfolipases (que são específicas para a anandamida e 2-AG), que convertem os fosfolipídeos em endocanabinoides (Piomelli, 2003). A partir daí, eles parecem atingir a fenda sináptica por meio de difusão e se acoplam aos receptores CB1 pré-sinápticos ligado à proteína Gi. $\mathrm{O}$ resultado da ativação desses receptores é a diminuição do influxo de cálcio nos terminais axônicos e, finalmente, diminuição da liberação do neurotransmissor (Saito et al., 2010).

A partir de diversos estudos realizados nos últimos anos, foi possível definir com precisão a composição do SE. De forma resumida, a atividade do SE envolve a: (1) síntese dos endocanabinoides no neurônio pós-sináptico, (2) 
sua ligação no receptor pré-sináptico CB1, (3) captação dos endocanabinoides na fenda sináptica e (4) a sua degradação por enzimas específicas (Figura 1). Com isso, foi possível desenvolver vários mecanismos farmacológicos capazes de interferir nesse sistema.

A forma mais direta de se manipular o SE é a partir da modulação de seus receptores canabinoides por meio de agonistas ou antagonistas. Estudos demonstram a possibilidade do uso de alguns agonistas e antagonistas para uso terapêutico em humanos, como, por exemplo, antagonistas de CB1 (Le Foll B \& Goldberg, 2005), e o uso de agonistas de CB2 em estudos pré-clínicos (Pertwee, 2006).

Os agonistas são moléculas capazes de ativar receptores do SE, ao passo que os antagonistas inibem a ação endocanabinoide. $O$ primeiro composto que se demonstrou capaz de bloquear esse sistema foi o SR 141716A (SR1 - Rimonabanto, Howllet et al., 2002). Dentro dessa família, outro antagonista bastante empregado é o AM 251. Esses compostos apresentam seletividade para o receptor $C B 1$ de 100 a 1000 vezes maior do que para o receptor CB2 (Pertwee, 2005).

Tais compostos permitiram estudos do papel fisiológico dos endocanabinoides além de possibilitar novos caminhos em pesquisas para 0 tratamento de dor, de doenças neurológicas e de desordens psiquiátricas. Nesse sentido, estudos recentes vêm indicando uma relação entre 0 funcionamento dos receptores do SE em alguns distúrbios psiquiátricos e do desenvolvimento bastante complexos, como o autismo (Schneider \& Koch, 2005; Markram et al. 2007; Markram et al., 2008; Parolaro et al., 2010; GarciaGutierrez \& Manzanares, 2011). 


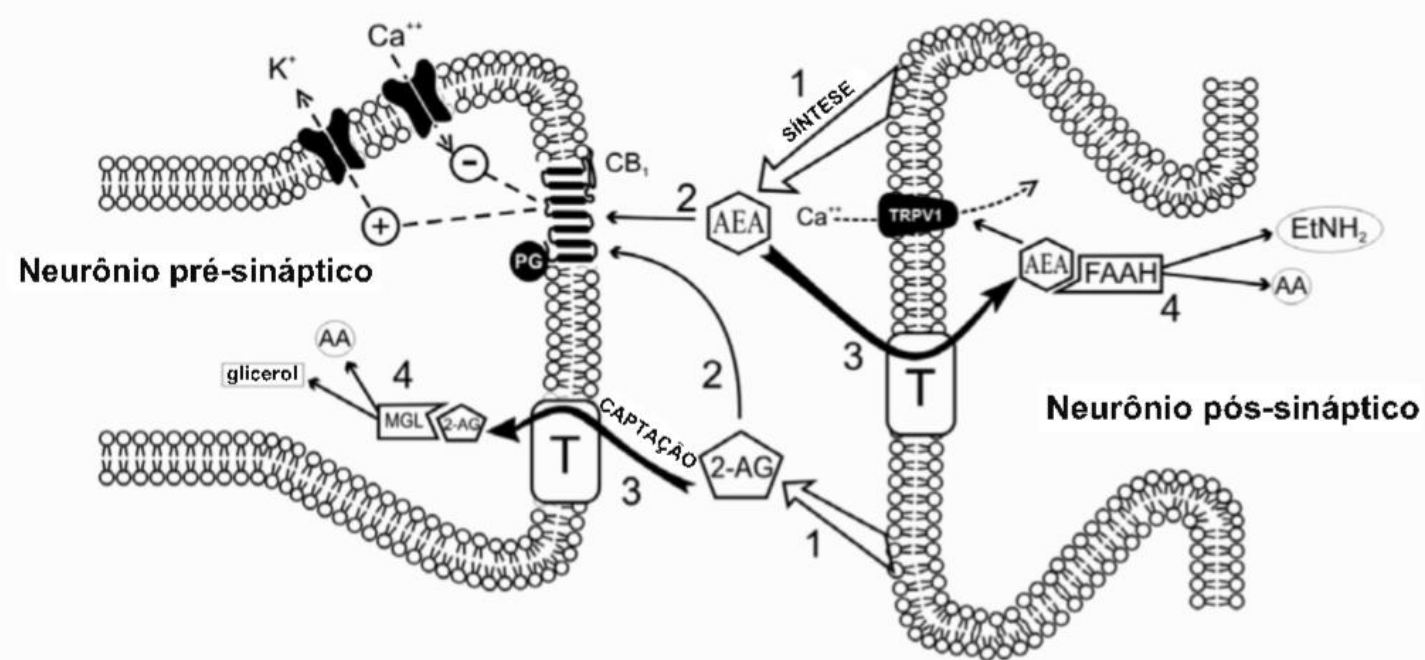

Figura 1. Representação esquemática do SE. Síntese dos endocanabinoides pelo neurônio pós-sináptico (1); ligação dos e SE com o receptor CB1, restringindo a atividade neural (2); captação na fenda sináptica - 2-AG pelo neurônio pré-sináptico e anandamina pelo neurônio pós-sináptico (3); e degradação dos e SE (4). (Adaptado de Saito et al., 2010)

\subsection{Transtornos do Espectro do Autismo (TEA)}

Os transtornos do espectro do autismo (TEA) incluem um amplo grupo de desordens neurológicas e comportamentais, que não são necessariamente originadas a partir dos mesmos fatores etiológicos (Buxbaum, 2009; Polsek et al., 2011; Betancur, 2011; Schaefer et al., 2013). Há poucos estudos sobre a prevalência do autismo em uma única população. O primeiro estudo epidemiológico, realizado em 1966 na Inglaterra, registrou uma prevalência de 4,5 casos por 10 mil habitantes, entretanto tem-se observado um aumento significativo no número de casos (Tuchman \& Rapin, 2009). Não se sabe exatamente se esse aumento é decorrente da mudança no método de diagnóstico do transtorno ou se existe algum fator ambiental que possa influenciar a sua ocorrência. Um relatório do CDC (Center for Disease Control and Prevention), órgão do governo dos Estados Unidos para controle e prevenção de doenças, estima que a cada 50 crianças uma é diagnosticada com autismo naquele país (CDC, 2012). Além disso, acredita-se que há mais de 67 milhões de pessoas com autismo no mundo (Kopetz \& Endowed, 2012).

Os tratamentos atuais consistem em intervenções educacionais precoces, baseadas em comportamento, em conjunto a uma série de terapias reabilitadoras suplementares. A intervenção farmacológica pode ser utilizada 
como uma terapia auxiliar, podendo diminuir alguns comportamentos específicos. Entretanto, ainda não existe um tratamento efetivo para o distúrbio em que se evidenciem alterações nos déficits centrais de comunicação social (Tuchman \& Rapin, 2009).

Disfunções na interação social e na extinção de memória aversiva são duas das muitas manifestações características do TEA (Buxbaum, 2009; Polsek et al., 2011; Betancur, 2011; Schaefer et al., 2013). Apesar dos TEA estarem estabelecidos somente para humanos, estudos mostraram que tais traços fenotípicos aparecem em camundongos knockout para o gene que codifica o receptor canabinoide CB1 (Litvin et al., 2013). Eles também são detectados em roedores cujas mães foram tratadas com ácido valproico durante a prenhez (Markram et al., 2008). Estes resultados aproximam-se das alterações comportamentais observadas em pacientes cujas mães ingeriram ácido valproico também durante a gestação (Markram et al., 2007).

É possível, portanto, que algumas características induzidas pelo tratamento com ácido valproico possam estar relacionadas com defeitos na sinalização do sistema endocanabinoide. Esta hipótese é consistente com descobertas recentes que demonstram alterações nos níveis de mRNA para uma das enzimas responsáveis pela síntese do endocanabinoide 2-AG, a $\alpha$ diacilglicerol lipase (Kerr et al., 2013) . Nesse estudo, foram demonstrados altos níveis de mRNA no cerebelo de ratos nascidos de fêmeas tratadas com ácido valproico. Além disso, os mesmos animais exibiram um aumento da atividade da enzima que degrada o 2-AG, a lipase monoacilglicerol, o que evidencia a ocorrência de importantes alterações nos sistemas endocanabinoides nesses modelos animais de autismo.

Os estudos com modelos animais empregando ácido valproico ou indivíduos knockout sugerem, portanto, que alterações no sistema endocanabinoide estão associadas a características fenotípicas do autismo.

\subsubsection{Interação social}

Déficits na interação social de pacientes com TEA são normalmente manifestados como isolamento social ou comportamento social inadequado. Entre essas alterações comportamentais, evitar o contato visual direto, mostrar 
indiferença a afeições ou afeição inapropriada, não participar de atividades em grupo, não responder quando é chamado e ausência de empatia social ou emocional denotam uma ampla extensão de prejuízos sociais recíprocos (Tuchman \& Rapin, 2009).

Existem diversos estudos comportamentais que mostram a participação do SE na exibição de comportamentos sociais (Haller et al., 2004; Dubreucq et al., 2011). Litvin e colaboradores (2013), por exemplo, demonstraram que a sinalização do receptor CB1 regula a ansiedade social e a memória em roedores. Neste estudo os animais que receberam doses agudas do antagonista AM 251 apresentaram um perfil comportamental de ansiedade, manifestado em alterações do comportamento social. Outro estudo (Trezza et al., 2012) mostrou que endocanabinoides localizados no complexo amigdaloide e do núcleo acumbens, áreas envolvidas na emoção e motivação, respectivamente, medeiam a 'brincadeira social' em ratos. A 'brincadeira social', um tipo de comportamento social de jovens mamíferos, é essencial para o desenvolvimento de habilidades físicas, cognitivas e sociais (Pellis \& Pellis, 2009; Trezza et al., 2010). Tal estudo mostrou que após a administração sistêmica de um agonista indireto do SE houve um aumento do comportamento de 'brincadeira social', e a administração de um antagonista na amígdala basolateral reduziu esse comportamento. Por fim, foi demonstrado também que um aumento nos níveis da sinalização de anandamida na amígdala e no núcleo acumbens aumenta este comportamento em ratos jovens.

Trezza e Vanderschuren (2008) evidenciaram que a administração de um agonista indireto do sistema endocanabinoide, que inibe a hidrólise de AEA, aumenta o comportamento de 'brincadeira social' em ratos jovens. Tal efeito dependia da estimulação de receptores opioides e dopaminérgicos. Assim, a liberação de endocanabinoides sob demanda facilita a interação social, que é ampliada por agonistas canabinoides indiretos por meio de uma interação com a neurotransmissão opioide e dopaminérgica.

A partir desses estudos, é possível afirmar, então, que a neurotransmissão canabinoide exerce um papel importante na modulação de comportamentos sociais dos indivíduos. 


\subsubsection{Extinção de memória aversiva}

A memória é a capacidade dos seres vivos de adquirir, reter e utilizar informações ou conhecimentos (Tulving, 1987). Compreende um conjunto de habilidades mediadas por diferentes módulos do sistema nervoso que funcionam de forma independente, porém cooperativa (Xavier, 1993).

O processo de memorização ocorre em diferentes estágios (Tomaz, 1993). A aquisição é a primeira etapa, e consiste na entrada da informação processada pelos sistemas sensoriais nos sistemas neurais ligados à memória. Tal informação é processada e armazenada no sistema de curto prazo. Após isso, inicia-se o processo de consolidação, que visa a estabilização e armazenamento em uma memória de longa duração. O último processo é chamado de evocação, onde a informação é recuperada e desencadeia respostas comportamentais e fisiológicas (Lent, 2010). No momento da evocação, as memórias latentes tornam-se lábeis, podendo ser extintas (Izquierdo et al., 1965), reconsolidadas (Nader, 2003), ou podem ainda incorporar novas informações de natureza cognitiva (Loftus \& Palmer, 1974) ou neurohumoral (Izquierdo et al., 1989).

A memória aversiva é um processo neural existente em vários animais, e, do ponto de vista anatômico, está intimamente ligada à amígdala (Maren \& Quirk, 2004, Figura 2). Há muitos estudos que mostram o papel essencial dessa estrutura cerebral no processamento de emoções, principalmente relacionado a respostas a estímulos de ameaça ou potencialmente perigosos (LeDoux, 1996; Tomaz et al., 2003; LeDoux, 2007). A amígdala recebe diversas aferências de áreas corticais sensoriais. Ademais, estabelece contato com áreas corticais e subcorticais relacionadas ao comportamento motor, regulação autonômica e visceral, e também de áreas responsáveis por atividades cognitivas avançadas (Amaral et al., 1992; Aggleton \& Saunders, 2000). Além da amígdala, estudos demonstram grande importância do hipocampo (Figura 2) em processos de aquisição e consolidação de memória aversiva (Kim \& Fanselow, 1992; Maren, 2001), e do córtex pré-frontal (Figura 2), que é ativado durante os processos de extinção de memória aversiva (Fiorenza et al., 2012). 
Indivíduos com TEA apresentam um processamento anormal na amígdala, o que pode ser central para a geração de medos excessivos observados no autismo (Markram et al., 2008). O processo denominado de extinção de memória aversiva pode ser verificado experimentalmente a partir do condicionamento Pavloviano de medo. Basicamente, este procedimento comportamental implica no aprendizado de que certos estímulos ambientais (pistas cognitivas) antecipam eventos aversivos. Um estímulo inicialmente neutro, após repetidos pareamentos com um estímulo aversivo (estímulo incondicionado), adquire a capacidade de induzir reações comportamentais associadas a este estímulo aversivo. Estabelecida esta associação, reações comportamentais e fisiológicas inatas em respostas a estímulos ameaçadores são expressos unicamente com a presença do estímulo neutro, agora denominado 'estímulo condicionado'. No entanto, se os animais são repetidamente expostos ao estímulo condicionado, na ausência do estímulo incondicionado, essa resposta condicionada tende a desaparecer. Este fenômeno denomina-se 'processo de extinção' (Lin et al., 2008). Pacientes com TEA apresentam um prejuízo nesse processo, de forma que a extinção das memórias aversivas seja retardada ou até mesmo não ocorra (Markram et al., 2008).

O estudo realizado no laboratório do Dr. Henry Markram demonstrou que camundongos nascidos de fêmeas tratadas com ácido valproico apresentam alterações neurofisiológicas e estruturais bem definidas no córtex pré-frontal. Essas alterações são refletidas no controle da plasticidade sináptica e atividade neuronal na amígdala basal, que contém os principais circuitos envolvidos na aquisição e extinção de memórias emocionais, principalmente as aversivas, e na expressão de comportamento relacionado à emoção (Rinaldi et al., 2008; Silva et al., 2009).

Diversos estudos em roedores mostram a relação do SE com processos da memória aversiva (Arenos et al., 2006; Lisboa et al., 2010; Abush \& Akirav, 2010; Alvares et al., 2010; Ratano et al., 2014; Simone et al., 2014). Lin e colaboradores (2008) demonstraram o papel de receptores CB1 do córtex préfrontal na modulação de memória aversiva. Foi observado que o $A M 251$, antagonista de $\mathrm{CB} 1$, retardou a extinção da memória aversiva em roedores. Em 
contrapartida, a ativação de receptores CB1 com agonistas do SE resultou em maior facilidade do indivíduo para extinguir tal memória.

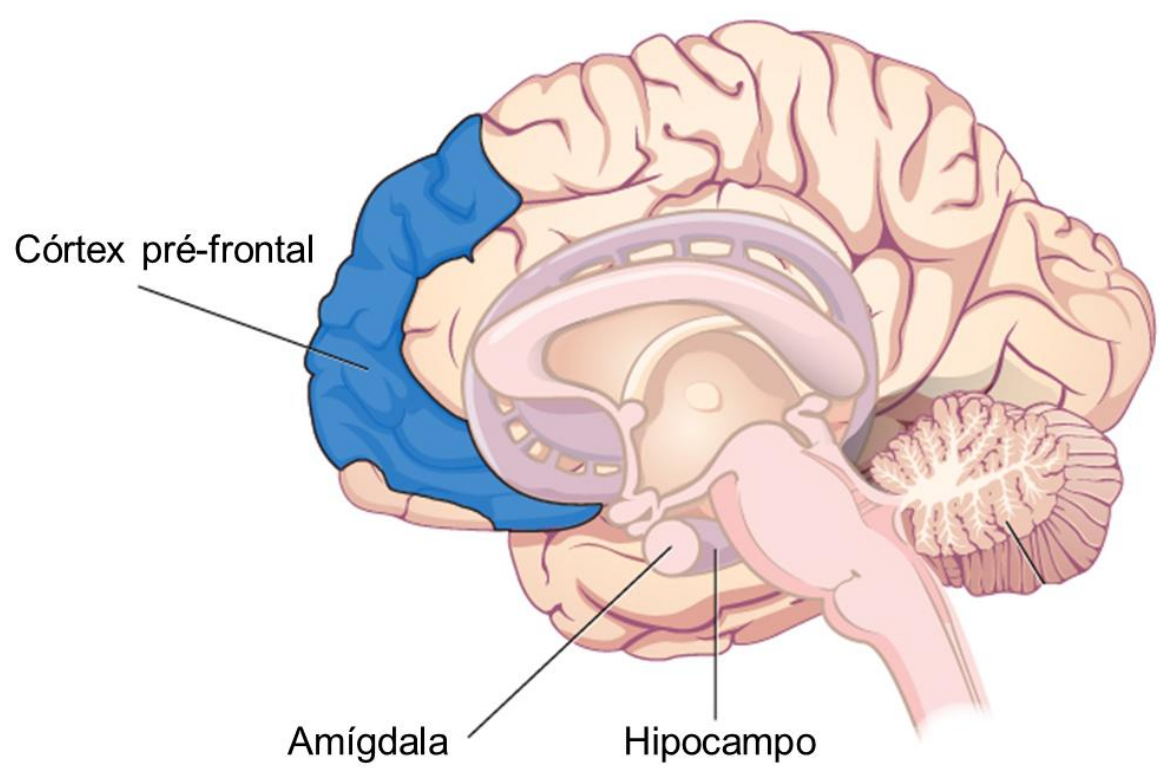

Figura 2. Regiões cerebrais envolvidas na memória aversiva: córtex préfrontal, amígdala e hipocampo. Fonte: Candela Open Courses (modificado).

\subsection{Uso de primatas em pesquisas}

Primatas não-humanos apresentam uma grande similaridade filogenética com seres humanos (Bontrop, 2011). Em razão disso, esses animais tornaramse importantes sujeitos experimentais em pesquisas biomédicas por permitir uma melhor generalização dos resultados para os casos com seres humanos. (Bontrop, 2011).

Neste estudo, foram utilizados indivíduos do gênero Sapajus (Alfaro et al., 2012, Figura 3) conhecidos popularmente como macacos-prego. Estes animais são encontrados na América do Sul, com extensão da Amazônia até o sul do Brasil, passando pelo cerrado na região central (Alfaro et al., 2012). Sua alimentação consiste de pequenos vertebrados e invertebrados, frutas, folhas e ovos (Chapman \& Fedigan, 1990; Canale et al., 2013). São animais de porte médio, pesando entre 2,0 e $4,5 \mathrm{~kg}$, e apresentam grande longevidade, chegando a viver até 45 anos de idade em cativeiro. 
Os macacos-prego destacam-se por serem animais de grande capacidade cognitiva, capazes de utilizar objetos como ferramentas, transmitir conhecimento social, além de apresentarem um complexo repertório comportamental (Fragaszy et al., 2004). Exibem grande variação de expressões faciais, em função de sua musculatura facial bem desenvolvida, e corporais, que são importantes na comunicação social (Fragaszy et al., 2004). Ademais, conseguem discernir facilmente os sinais de outros indivíduos em virtude de sua excelente acuidade visual (Weigel, 1978). Sendo assim, todas estas características justificam o grande interesse científico neste gênero para pesquisas sobre cognição e comportamento social.

No presente trabalho, avaliou-se o papel do SE na interação social e extinção de memória aversiva em macacos-prego. Há vários estudos na literatura que evidenciam a importância da sinalização do SE em processos de aprendizagem e respostas comportamentais em roedores. Além disso, muitas pesquisas apontam defeitos metabólicos na biossíntese ou na resposta dos endocanabinoides, possibilitando um modelo animal para testar novos tratamentos farmacológicos que atenuem alguns traços do autismo (Markram et al., 2007; Kerr et al., 2013, Litvin et al., 2013). Contudo, não foram encontrados, na literatura científica, estudos em primatas que avaliem estas questões.

É importante destacar a grande semelhança do perfil farmacológico entre primatas humanos e não-humanos (Maior et al., 2011b). Apesar da importância de estudos psicofarmacólogicos com roedores, existem diferenças comportamentais e na distribuição e atividade de receptores CB1 entre estes e primatas não-humanos (Ong \& Mackie, 1999). Assim, estudos com estes sujeitos experimentais permitem resultados com maior possibilidade de generalização para tratamento em humanos.

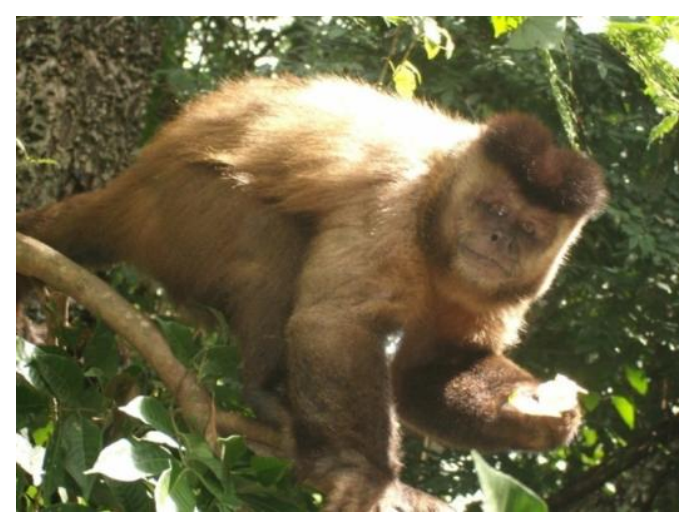

Figura 3. Fotografia do macaco-prego adulto (Sapajus spp) em seu habitat natural. Foto: 


\subsection{OBJETIVOS}

\subsection{Objetivo Geral}

- Avaliar o papel do sistema endocanabinoide na interação social e na extinção de memória aversiva em macaco-prego (Sapajus spp) a partir do bloqueio do receptor CB1 pelo seu antagonista AM 251.

\subsection{Objetivos Específicos}

- Estudo 1:

- Comparar comportamentos espontâneos (sociais e nãosociais) de machos Sapajus spp após a administração de três doses diferentes de AM 251 (3,0, 1,0 e 0,3 mg/kg, i.m.) e veículo;

- Comparar os comportamentos espontâneos (sociais e nãosociais) observados após a administração dos diferentes tratamentos com a linha de base de comportamentos dos próprios sujeitos;

- Selecionar a melhor dose de AM 251 para o Estudo 2;

- Estudo 2:

- Comparar a latência para extinção de memória aversiva entre o grupo controle e o tratado com AM 251. 


\subsection{MATERIAIS E MÉTODO - ESTUDO 1 (Avaliação do papel do SE na interação social em macacos-prego.)}

\subsection{Considerações éticas}

Este trabalho foi avaliado e aprovado pela Comissão de Ética no Uso Animal (CEUA) do Instituto de Ciências Biológicas da Universidade de Brasília (UnBDoC no 46060/2014) (Anexo I). O presente estudo segue as diretrizes do Conselho Nacional do Controle de Experimentação Animal (CONCEA) e a Lei Federal no 11.794/08 (Lei Arouca).

\subsection{Local do estudo}

Este trabalho foi realizado no Centro de Primatologia (CP), localizado na Fazenda Água Limpa (FAL) da Universidade de Brasília, a cerca de $25 \mathrm{~km}$ de distância do centro de Brasília, no Distrito Federal. A FAL possui uma área de 4.340 ha, dos quais metade corresponde à área de preservação ambiental.

O CP é credenciado pelo Instituto de Meio Ambiente e dos Recursos Naturais Renováveis (IBAMA) como criadouro de primatas para fins científicos (Registro IBAMA, 1/53/1999/000006-2), dispondo de assistência médico veterinária permanente. Os animais ficam alojados em viveiros situados em meio à vegetação local, próximos à mata de galeria, e são mantidos segundo as normas de manutenção de animais em cativeiro do IBAMA.

\subsection{Sujeitos}

Foram utilizados cinco macacos-prego (Sapajus spp) machos adultos. Neste estudo foram testados apenas machos, pois estes apresentam menor variação hormonal do que fêmeas. Estes animais estavam alocados em viveiros de $4 \mathrm{~m}$ de comprimento $\times 2,5 \mathrm{~m}$ de largura $\times 3 \mathrm{~m}$ de altura (Figura 4). Os animais foram mantidos em tríades, consistindo em um macho e duas fêmeas por viveiro. Os animais são mantidos em viveiros sob condições naturais de temperatura, umidade e luminosidade. Sua alimentação consistiu em frutas, 
legumes, verduras, ovos, frango, larvas de tenébrios e ração, sendo fornecida água ad libitum.
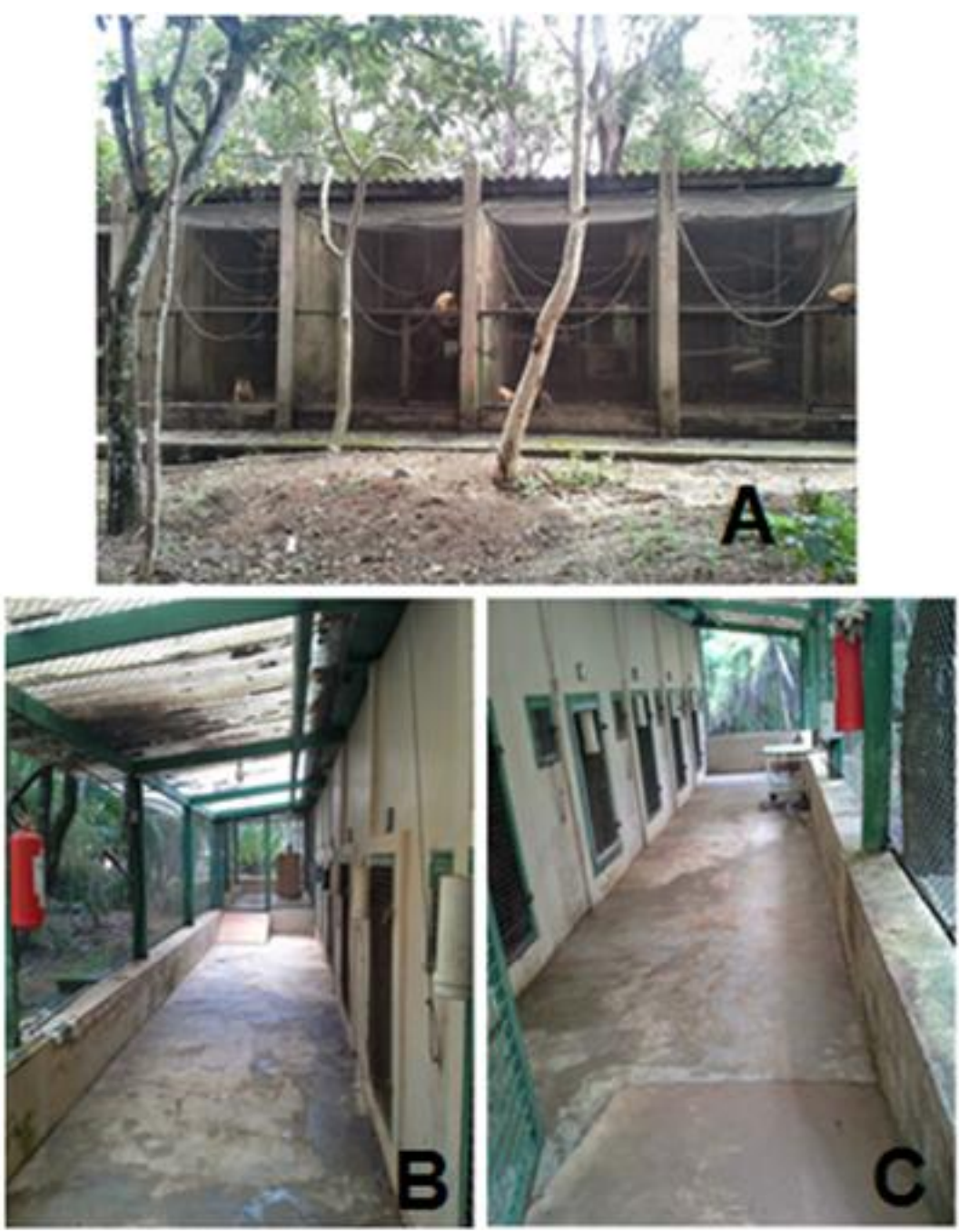

Figura 4. Pavilhão Central dos Sapajus spp. (A) Vista frontal dos viveiros. (B e C) Vista da área de manutenção dos viveiros. Fotos: Mariana Jacobsen

\subsection{Compostos}

A droga utilizada foi um antagonista do receptor CB1 do Sistema Endocanabinoide, o AM 251 (Howlett et al., 2002; Sigma-Aldrich, Brasil).

Para este estudo foram preparadas três soluções com diferentes doses de AM 251 (3,0, 1,0 e 0,3 mg/kg, i.m.) e solução veículo. O preparo consistiu na 
dissolução do antagonista AM 251 em uma solução veículo contendo Tween 80 e salina na proporção de 1:9. As doses foram separadas em frascos de plástico estéreis e congeladas a $-80^{\circ} \mathrm{C}$. A via de administração da droga foi intramuscular no volume de $1 \mathrm{~mL} / \mathrm{kg}$, aplicada 30 minutos antes do início da cada sessão. A eficácia da via de administração, assim como as doses a serem empregadas foram determinadas a partir de estudos anteriores que empregaram roedores e primatas não-humanos e fármacos com efeitos no sistema endocanabinoide (Rodgers et al., 2005; Delatte \& Paronis, 2008; Schindler et al., 2010; Cagni \& Barros, 2013).

\subsection{Procedimento experimental}

A coleta dos dados foi realizada nos meses de Dezembro de 2014 e Janeiro de 2015 , no período matutino, de $7 \mathrm{~h} 30$ às $11 \mathrm{~h} 30$. Foram observados os comportamentos espontâneos sociais e não-sociais de machos vivendo em tríade (um macho para duas fêmeas), sendo cinco tríades. Os sujeitos não foram privados de alimento durante as sessões. Duas vezes por semana (nas segundas e quintas-feiras) eles recebiam ração pela manhã, e nos outros dias da semana a alimentação era de frutas e verduras.

Primeiramente, foram realizadas cinco sessões de linha de base para cada tríade, totalizando vinte e cinco sessões. O período de realização desta etapa foi entre os dias 15 e 20 de dezembro de 2014. Cada sessão teve a duração de 30 minutos, sendo uma sessão por dia para cada tríade. Os comportamentos foram filmados por meio de uma câmera digital (Sony Cybershot DSC-W730) e os vídeos analisados. A câmera digital foi posicionada na parte frontal de cada viveiro (Figura 4A), de forma que todo o espaço ocupado pelos animais era abrangido. A ordem de filmagem das tríades foi pseudoaleatorizada, de forma que nenhuma tríade foi filmada mais de uma vez no mesmo horário. Nas sessões de linha de base, não houve manipulação (e.g., captura, separação, administração de drogas) dos animais. Durante as sessões, nenhum experimentador permaneceu no local próximo aos viveiros dos animais, exceto nos momentos de início e fim da gravação.

Após as sessões de linha de base, iniciaram-se as sessões de testes com as doses de AM 251 e o veículo. O período de realização das sessões de 
teste foi entre os dias 6 e 20 de janeiro de 2015. As sessões de testes foram realizadas da mesma maneira que as da linha de base, exceto pela administração da solução de AM 251 e de veículo. Foi realizada uma sessão para cada dose em cada macho, com intervalo de, no mínimo, 48h entre as sessões de cada sujeito. Para administrar o fármaco, os animais foram capturados em seus viveiros por meio de um puçá e, enquanto capturados, foram injetados com a respectiva dose do fármaco. Após a administração, os animais foram devolvidos a seus viveiros. As observações tiveram início 30 minutos após a administração da droga ou veículo e os comportamentos de cada sujeito foram gravados por câmera digital e analisados posteriormente.

A ordem de administração dos tratamentos nos animais foi feita de forma pseudo-aleatória, bem como a sequência das doses a serem aplicadas em cada dia.

\subsection{Análise de dados}

Os comportamentos dos animais foram gravados com o auxílio da câmera de vídeo e analisados posteriormente pelos experimentadores. Para análise dos vídeos foi utilizado o método de observação por sujeito-focal (Altmann, 1974), com registro contínuo (duração em segundos) e registro instantâneo (frequência) de cada comportamento espontâneo e social apresentado pelos machos.

Os comportamentos espontâneos dos animais foram analisados baseados nas seguintes definições (Boinski et al., 1999; Fragaszy et al., 2004; Rodrigues, 2010; Campos \& Fedigan, 2014):

- Alimentação: mastigar e ingerir item alimentar;

- Forrageio: deslocar pelo recinto à procura de alimentos, cheirar, lamber e vistoriar substratos;

- Coçar: utilizar mãos ou pés para coçar (esfregar) alguma parte do corpo;

- Autocatação: limpar/catar com os dedos o próprio pelo;

- Inatividade: ausência de atividade locomotora ou engajamento em algum comportamento específico. Inclui descansar, dormir, deitar. 
- Vigilância: estado estacionário e em alerta do animal. Olhar fixamente para alguma parte dentro ou fora do viveiro, monitorando o ambiente;

- Cavar: utilizar membros anteriores durante a interação com o solo do viveiro;

- Brincar no balanço: locomover-se de um lado para o outro utilizando o balanço;

- Manipular objeto: utilizar ferramentas, como pedras e galhos;

- Locomoção: deslocamento ou movimentação do animal pelo recinto;

Com o objetivo de facilitar as análises alguns comportamentos que estão relacionados foram agrupados. Os agrupamentos foram:

- Comportamentos autodirigidos: autocatação e coçar;

- Comportamentos que envolvem manuseio de substrato: cavar, brincar no balanço e manipular objeto.

Foram considerados os seguintes comportamentos sociais para análise de cada sujeito (Maior, 2011):

- Aproximar-se: deslocar em direção a outro indivíduo e permanecer próximo a uma distância não maior que um braço (do animal) por pelo menos 1 segundo;

- Contato físico: manter contato físico com um ou mais animais por pelo menos 1 segundo;

- Limpeza social (allogrooming): limpar/catar com os dedos no pelo de outro animal por pelo menos 1 segundo;

- Brincar: interagir com outros animais com contato físico, mordiscos e agarros não agressivos;

- Exploração ano-genital: farejar ou aproximar as narinas à região ano-genital de outros animais;

- Seguir: locomover-se seguindo a trajetória de outro animal a uma distância menor que um braço por pelo menos 1 segundo; 
- Aceitar proximidade: permanecer no mesmo local após a chegada de outro animal por pelo menos 1 segundo;

- Contato visual: dirigir o olhar para o rosto de outro animal em reciprocidade com o mesmo.

Após análise dos vídeos todos os dados foram tabulados no programa Excel 2013 e foram calculados a média e o erro padrão, como valores de referência. Para a análise estatística, foi utilizado o programa SPSS (Statistical Package for Social Sciences) versão 20.0 para Windows.

Os dados das amostras foram submetidos a variados tipos de testes estatísticos. Primeiramente foi utilizado o teste de normalidade de Shapiro-Wilk para cada amostra. Todas as amostras apresentaram uma distribuição nãonormal. Por isso, foram testadas com o teste de Friedman a título de conhecimento sobre alguma diferença entre as sessões e, caso constatadas diferenças estatisticamente significativas, foi utilizado o teste de Wilcoxon para se identificar qual(is) tratamento(s) diferia $(\mathrm{m})$ dos demais. Para todos os testes estatísticos realizados o nível de significância foi estabelecido em $p \leq 0,05$. 


\subsection{RESULTADOS - ESTUDO 1}

\subsection{Comportamentos espontâneos não-sociais}

A Figura 5 apresenta os resultados obtidos para a duração da locomoção dos cinco indivíduos em cada tratamento (veículo, dose $0,3 \mathrm{mg} / \mathrm{kg}$, dose $1,0 \mathrm{mg} / \mathrm{kg}$, dose $3,0 \mathrm{mg} / \mathrm{kg}$ ) e na linha de base, durante as sessões de 30 minutos (1800 segundos). Em relação ao comportamento de atividade locomotora dos indivíduos, não foi observada diferença significativa entre as sessões. Para o comportamento de vigilância dos animais, também não foram detectadas diferenças estatísticas significativas entre as sessões (Figura 6).

\section{Locomoção}

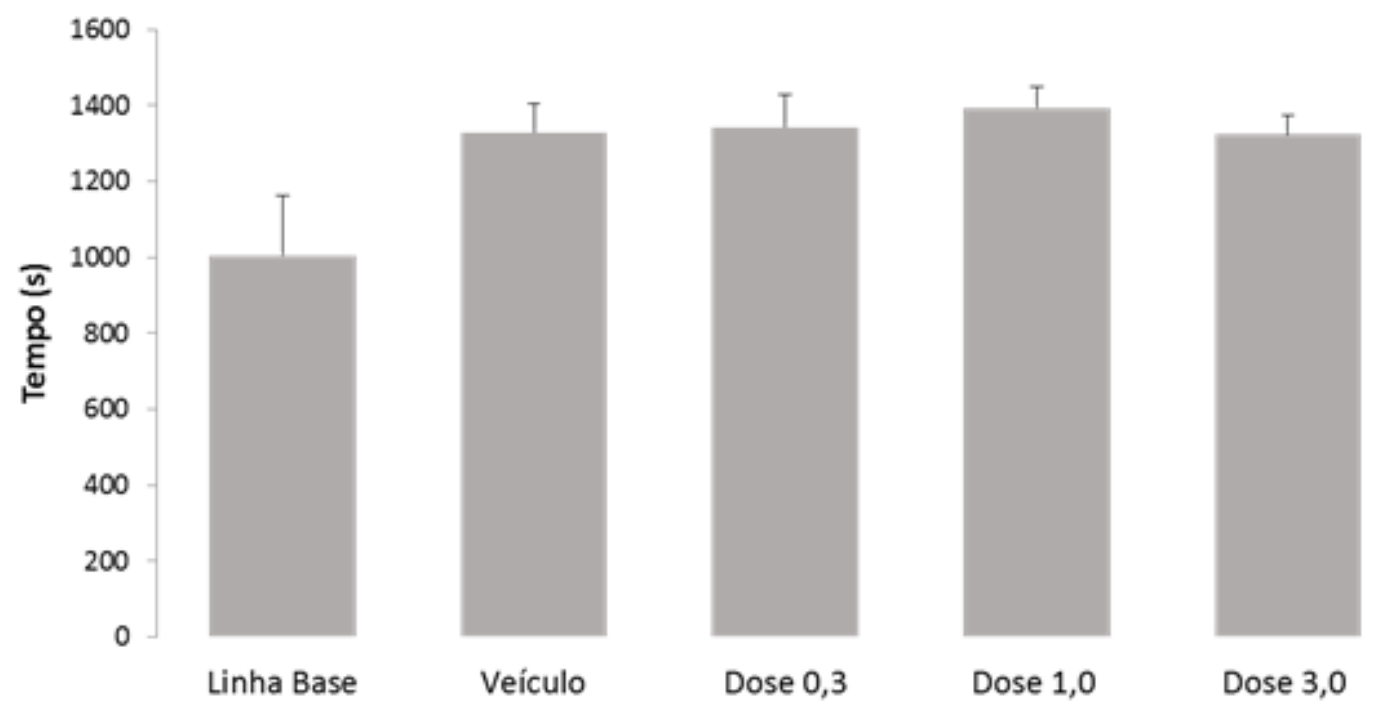

Figura 5. Média do tempo de locomoção das sessões experimentais ( \pm E.P.M.), em segundos. $n=5$

Em relação aos comportamentos autodirigidos (Figura 7), que incluem os comportamentos de coçar e de autocatação, foi observado que a frequência desses comportamentos na dose $3,0 \mathrm{mg} / \mathrm{kg}$ diferiu da linha de base e das outras duas doses empregadas $(Z=-2,023, p<0,05$ entre dose maior e dose intermediária, e Z- -2,041, $p<0,05$ entre dose maior e dose menor). Além disso, foi observada uma diferença entre a dose de $0,3 \mathrm{mg} / \mathrm{kg}$ e a linha de base ( $Z=-$ 2,023, $p<0,05)$. Quando comparados a frequência dos comportamentos 
autodirigidos entre o veículo e a dose de $3,0 \mathrm{mg} / \mathrm{kg}$ foi obtido o valor de $p=0,08$ $(Z=-1,753)$. Não houve diferença estatística entre linha de base e veículo $(Z=-$ $0,944, p=0,345)$.

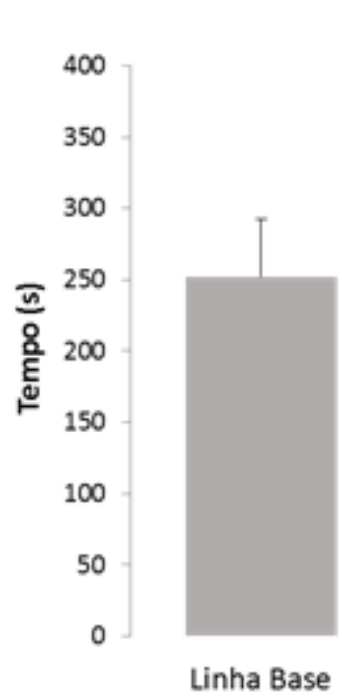

\section{Vigilância}
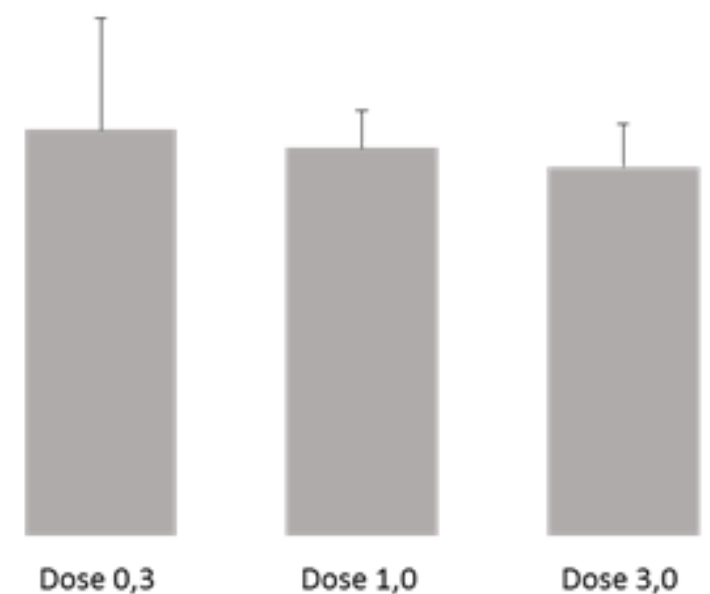

Veiculo

Dose 1,0

Dose 3,0

Figura 6. Média do tempo de vigilância das sessões experimentais ( \pm E.P.M.), em segundos. $n=5$

\section{Autodirigidos}
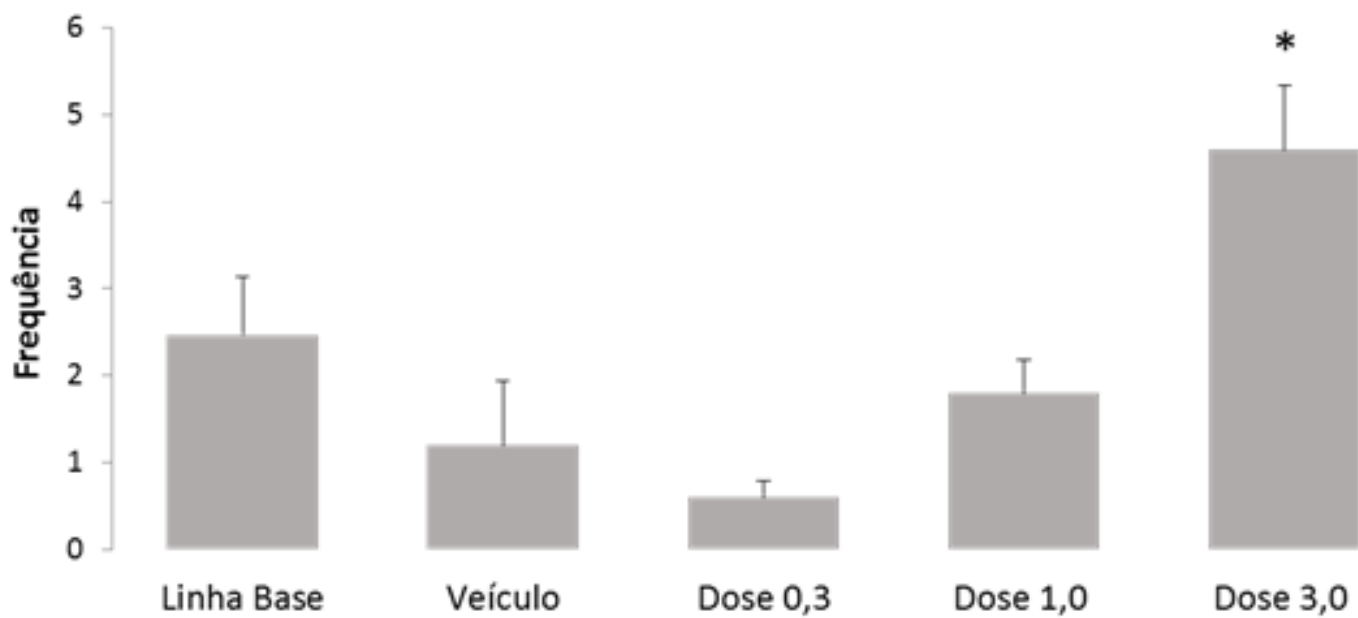

Linha Base

Veiculo

Dose 1,0

Dose 3,0

Figura 7. Média da frequência de comportamentos autodirigidos das sessões experimentais $( \pm$ E.P.M.), em segundos. $n=5$; * significa diferença da linha de base, dose 0,3 e dose 1,0.

Os resultados para o comportamento de forrageio estão apresentados na Figura 8. Foram observadas diferenças estatísticas significativas entre as 3 doses do AM 251 e a linha de base $(Z=-2,023, p<0,05)$. $O$ tempo de forrageio 
do tratamento com veículo alcançou $p=0,068(Z=-1,826)$ em relação às doses de 1,0 e de $3,0 \mathrm{mg} / \mathrm{kg}$ de AM 251.
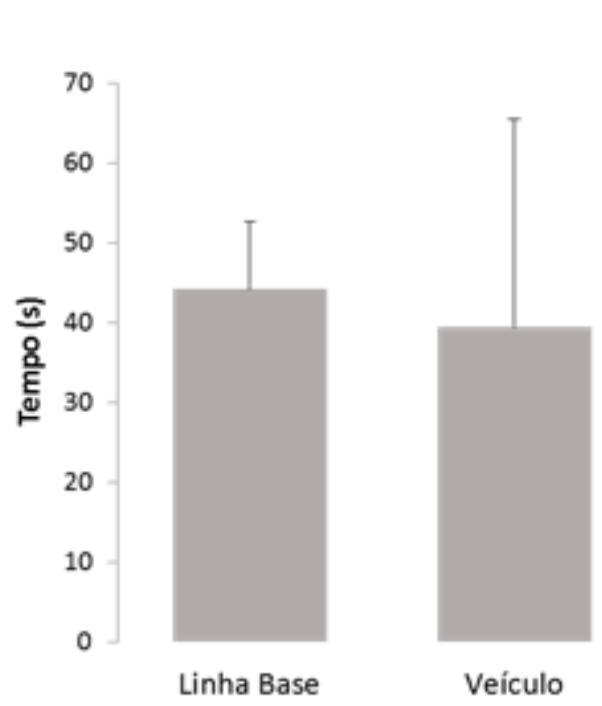

\section{Forrageio}
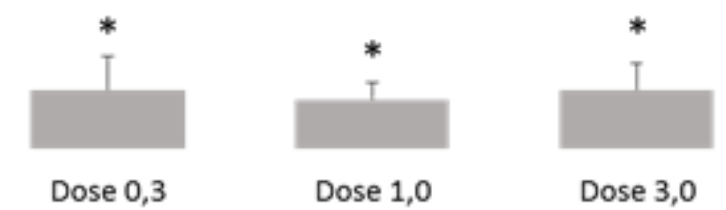

Figura 8. Média do tempo de forrageio das sessões experimentais ( \pm E.P.M.), em segundos. $n=5$; *significa diferença da linha de base.

A Tabela 1 apresenta as médias e erro padrão de outros comportamentos espontâneos avaliados neste estudo. Não houve diferença significativa entre as sessões para os comportamentos de repouso e manuseio de substrato. Já o comportamento de alimentação apresentou diferenças estatísticas significativas entre linha de base e veículo, e entre a linha de base e dose $1,0 \mathrm{mg} / \mathrm{kg}$.

Tabela 1. Média (erro padrão) do tempo de comportamentos espontâneos nãosociais observados nos cinco machos de Sapajus spp para cada sessão. * significa diferença estatística relativa à linha de base.

\begin{tabular}{c|ccc}
\hline \multirow{2}{*}{ Sessões } & \multicolumn{3}{|c}{ Comportamentos } \\
& Alimentação & $\begin{array}{c}\text { Manuseio de } \\
\text { substrato }\end{array}$ & Repouso \\
\hline $\begin{array}{c}\text { Linha de } \\
\text { base }\end{array}$ & $\begin{array}{c}168,32 \\
(36,30)\end{array}$ & $15,83(6,79)$ & $142,68(52,88)$ \\
\hline Veículo & $\begin{array}{c}71,2 \\
(30,82)^{*}\end{array}$ & $11,63(7,03)$ & $37,2(6,89)$ \\
\hline $\begin{array}{c}\text { Dose 0,3 } \\
\mathrm{mg} / \mathrm{kg}\end{array}$ & $45,8(29,71)$ & $14,56(10,68)$ & $55,8(38,18)$ \\
\hline
\end{tabular}




\begin{tabular}{c|llc}
\hline $\begin{array}{c}\text { Dose 1,0 } \\
\mathrm{mg} / \mathrm{kg}\end{array}$ & $40(11,20)^{*}$ & $11,33(8,79)$ & $28,8(10,74)$ \\
\hline $\begin{array}{c}\text { Dose 3,0 } \\
\mathrm{mg} / \mathrm{kg}\end{array}$ & $49,4(47,91)$ & $10,63(5,63)$ & $34,6(11,40)$ \\
\hline
\end{tabular}

\subsection{Comportamentos espontâneos sociais}

Entre os comportamentos sociais descritos, apenas três foram observados no presente estudo: 'seguir', 'aproximar-se' e 'aceitar proximidade' (Tabela 2). O comportamento de seguir foi observado apenas em um sujeito e, portanto, não foi incluído na tabela. Os três comportamentos sociais observados foram agrupados como 'Interação social'. Na Figura 9, são apresentados os resultados do tempo de interação social para os cinco sujeitos, em cada tratamento (linha de base, veículo, dose 0,3 $\mathrm{mg} / \mathrm{kg}$, dose 1,0 $\mathrm{mg} / \mathrm{kg}$, dose $3,0 \mathrm{mg} / \mathrm{kg}$ ). Foram observadas diferenças estatísticas significativas entre linha de base e as doses de 0,3 e $3,0 \mathrm{mg} / \mathrm{kg}$; e entre as doses de 1,0 e $3,0 \mathrm{mg} / \mathrm{kg}(Z=-2,023, p<0,05)$. Foi obtido 0 valor de $p=0,08$ $(Z=-1,753)$ na comparação entre veículo e dose $3,0 \mathrm{mg} / \mathrm{kg}$ de AM 251.

Tabela 2. Média (erro padrão) do tempo de dois comportamentos espontâneos sociais observados nos cinco machos de Sapajus spp para cada sessão. * significa diferença estatística relativa à linha de base.

\begin{tabular}{ccc}
\hline Sessões & \multicolumn{2}{c}{ Comportamentos sociais } \\
& Aproximar-se & $\begin{array}{c}\text { Aceitar } \\
\text { proximidade }\end{array}$ \\
\hline Linha de base & $31,08(7,69)$ & $9,8(2,85)$ \\
Veículo & $20,2(11,79)$ & $3,4(1,72)$ \\
Dose $0,3 \mathrm{mg} / \mathrm{kg}$ & $12(5,40)$ & $3,2(3,2)^{\star}$ \\
Dose $1,0 \mathrm{mg} / \mathrm{kg}$ & $19,4(5,60)^{\star}$ & $5,2(2,33)$ \\
Dose $3,0 \mathrm{mg} / \mathrm{kg}$ & $7,4(3,54)^{\star}$ & $0^{\star}$ \\
\hline
\end{tabular}




\section{Interação Social}

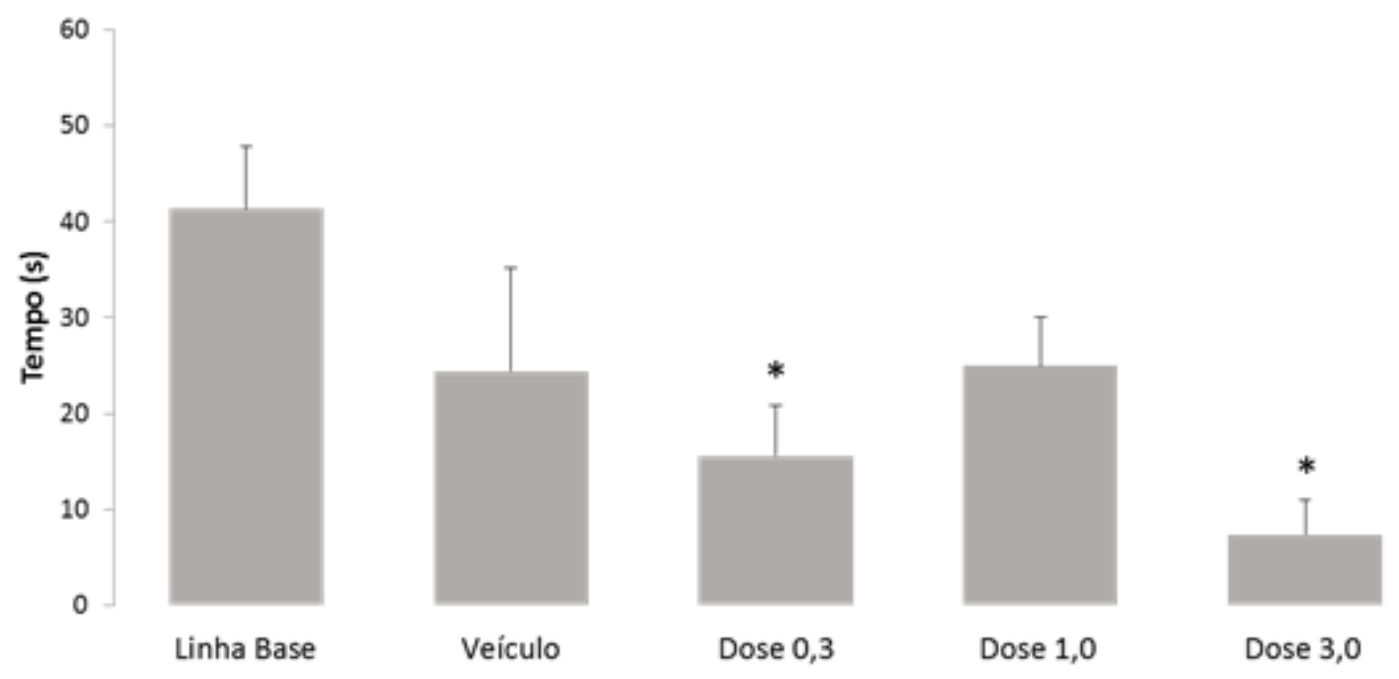

Figura 9. Média do tempo de interação social das sessões experimentais ( \pm E.P.M.), em segundos. $n=5$; * significa diferença da linha de base. 


\subsection{DISCUSSÃO - ESTUDO 1}

\subsection{Comportamentos espontâneos não-sociais}

\subsubsection{Locomoção}

Em relação à atividade locomotora, não foi observada diferença estatística significativa entre os tratamentos empregados e o veículo. Concluise então que nenhuma das doses de AM 251 empregadas neste estudo alterou a locomoção dos indivíduos. Houve uma tendência de maior atividade locomotora entre a linha de base e os demais tratamentos. Ainda que não significativa, esta tendência pode indicar uma alteração induzida pela captura durantes os tratamentos. Um estudo realizado com micos-estrela avaliou o efeito comportamental de dois ligantes do receptor CB1, o antagonista AM 251 e o agonista WIN 55,212-2, em um teste de campo aberto (Cagni \& Barros, 2012). Tal estudo também não detectou alteração na locomoção com a administração desses ligantes.

Para roedores, no entanto, mudanças na atividade locomotora são comumente percebidas em estudos com a modulação do sistema endocanabinoide. Estudos utilizando agonistas de CB1 demonstraram um efeito hipolocomotor em camundongos (Vlachou et al., 2003; Ossato et al., 2015). Järbe e colaboradores (2006) observaram um aumento na atividade locomotora com a administração do antagonista SR 141716 em ratos. Em contrapartida, uma supressão da locomoção induzida pela administração dos antagonistas de CB1, AM 251 e AM 4113, foi descrita por Sink e colaboradores, em 2009. Já no estudo de Reich e colaboradores (2008) sobre modulação do sistema endocanabinoide nas respostas de medo, uma dose de $5,0 \mathrm{mg} / \mathrm{kg}$ de AM 251, aplicada via intraperitoneal, não alterou a locomoção. Entretanto, neste mesmo trabalho, a dose de $10 \mathrm{mg} / \mathrm{kg}$ de AM 251 afetou significativamente a atividade locomotora dos indivíduos. Essa variação existente em roedores pode ser decorrente de diferentes doses e drogas empregadas nesses estudos.

Nota-se uma divergência em termos de efeitos locomotores entre primatas e roedores. Ong e Mackie (1999) relataram, em Macaca fascicularis, baixa densidade de receptores $\mathrm{CB} 1$ em regiões dos núcleos da base, ao passo 
que em roedores, uma grande quantidade destes receptores foi observada. Assim, a regulação da função motora mediada pelos receptores canabinoides e dopaminérgicos localizados nos núcleos da base parece ser mínima em primatas. Essas divergências podem ser explicadas por diferenças na localização e quantidade de receptores CB1 entre esses dois modelos experimentais.

\subsubsection{Vigilância e comportamentos autodirigidos}

A vigilância em macacos-prego é comumente referida como uma estratégia antipredatória, em que os animais cessam qualquer atividade e ficam sentados ou em pé, em posição de alerta, verificando visualmente o território (Fragaszy et al., 2004). Em um trabalho com Cebus capucinus (1995), Rose e Fedigan observaram que machos adultos tendem a ser mais vigilantes do que as fêmeas, e machos alfa são os mais vigilantes do grupo. No presente estudo, não foram detectadas diferenças significativas entre os tratamentos e a linha de base para o tempo de vigilância, ou seja, tal comportamento não foi afetado pelo AM 251 nas três doses testadas. As informações sobre o efeito desta droga no comportamento de vigilância são escassas. Um estudo em micosestrela demonstrou que após administração do antagonista AM 251 houve um aumento dos comportamentos relacionados à vigilância nos animais (Cagni et al., 2014). Isso pode indicar um perfil ansiogênico. É importante ressaltar que em nosso estudo os animais não foram retirados de seus viveiros de moradia e tampouco submetidos a um protocolo específico para avaliação da vigilância.

O comportamento de autocatação em macacos-prego selvagens, ocorre em resposta a estímulos nocivos sobre a pele ou pelagem, como por exemplo picadas de formigas ou cupins. Boinski e colaboradores (1999) categorizaram este comportamento como anormal em seus estudos com animais de cativeiro, por terem observado uma frequência muito maior nesses animais do que naqueles de vida livre. Comportamentos autodirigidos, como por exemplo, coçar, podem indicar um aumento na ansiedade em macacos-prego (Rimpley \& Buchanan-Smith, 2013). No entanto, esse aumento é percebido em conjunto com outros comportamentos relacionados à ansiedade, como o aumento da vigilância. 
Em nosso estudo, foi observado um aumento significativo dos comportamentos autodirigidos em função da administração do AM 251 na dose de $3,0 \mathrm{mg} / \mathrm{kg}$. Não foi detectada diferença entre o tratamento com veículo e o tratamento com as três doses. Entretanto, observou-se uma tendência a um aumento em relação ao veículo, principalmente na dose de $3,0 \mathrm{mg} / \mathrm{kg}$ de AM $251(Z-=1,753, p=0,08)$. Até o momento, não há relatos na literatura sobre a influência do SE em comportamentos autodirigidos. É importante que mais estudos sejam realizados, com um número maior de sujeitos, para que se possa interpretar com mais clareza os resultados encontrados até o momento.

\subsubsection{Forrageio}

Forrageio pode ser definido como o conjunto de estratégias utilizadas por um indivíduo para a obtenção de seu recurso (Pough et al., 2008). Sendo assim, este é um comportamento diretamente associado à alimentação.

Nossos resultados não apresentaram uma diferença estatística significante entre o tratamento com veículo e as doses de AM 251 ( $Z=-1,725$, $p=0,068$ entre veículo $\times$ dose $1,0 \mathrm{mg} / \mathrm{kg}$ e veículo $\times$ dose $3,0 \mathrm{mg} / \mathrm{kg}$ ). No entanto, é possível observar uma tendência à diminuição deste comportamento. Não foram encontrados, na literatura científica, estudos que avaliaram o papel do SE no comportamento de forrageio, contudo muito se sabe sobre a relação deste sistema com comportamentos alimentares.

Em seres humanos, um dos efeitos da Cannabis é a indução da busca por alimentos, principalmente alimentos palatáveis. Além disso, também é descrito o uso de canabinoides para alívio de anorexia e náuseas em doenças consumptivas (Godoy-Matos et al., 2006), o que sugere um forte papel do sistema endocanabinoide na modulação do apetite. Isso pode ser explicado pela alta concentração de endocanabinoides e receptores CB1 em áreas hipotalâmicas que estão envolvidas no controle alimentar, como os núcleos ventromedial, dorsomedial, lateral e paraventriculares (Godoy-Matos et al., 2006). Muitos estudos têm demonstrado que a administração de AM 251 e outros antagonistas de CB1 suprimem a ingestão de alimentos com diferentes composições de macronutrientes, incluindo alimentos altamente palatáveis e naturais (Arnone et al., 1997; Colombo et al., 1998; McLaughlin et al., 2003; 
Escartín-Pérez et al., 2008). Ademais, estudos com Rimonabant (SR 141716A), antagonista do receptor CB1 e da mesma família do AM 251, apresentaram uma forte diminuição na busca por alimentos palatáveis em animais alimentados ad libitum (Di Marzo \& Matias, 2005).

A partir dessas informações e dos resultados encontrados no presente estudo, é possível associar a diminuição no forrageio dos animais ao bloqueio do receptor CB1 pelo antagonista AM 251. Além disso, vale ressaltar que o reduzido número amostral pode ter reduzido o poder estatístico do teste realizado.

\subsection{Comportamentos sociais}

O sistema endocanabinoide têm se destacado como um importante neuromodulador na regulação de estados emocionais (Bari et al., 2006; Marco \& Laviola, 2011; Morena \& Campolongo, 2014). A inibição de enzimas responsáveis pela degradação de endocanabinoides tem sido uma das ferramentas para estudos envolvendo respostas motivacionais e emocionais em roedores (Di Marzo, 2009; Trezza et al., 2012). Já foi demonstrado que a administração desses inibidores, tanto de forma sistêmica, quanto diretamente em regiões límbicas cerebrais (núcleo acumbens e amígdala), aumenta a atividade social em ratos (Trezza et al., 2012). Ademais, camundongos knockout para o gene que codifica o receptor CB1 apresentam traços fenotípicos do autismo como, por exemplo, a diminuição na interação social dos indivíduos (Markram et al., 2008). Dessa forma, tem sido demonstrado um papel claro do sistema endocanabinoide para comportamentos sociais.

No presente estudo não foi observada diferença estatística significativa entre as sessões com administração de veículo e as três doses de AM 251. Não obstante, é possível notar uma tendência à diminuição de comportamentos sociais dos indivíduos com a administração do antagonista na dose de 3,0 $\mathrm{mg} / \mathrm{kg}(\mathrm{Z}=-1,753, p=0,08)$. Essa possível diminuição é condizente com um trabalho de Litvin e colaboradores (2013) em camundongos que indicou um aumento de comportamentos do tipo avoidance e ansiedade social, afetando o comportamento social dos indivíduos. Um estudo recente verificou o papel dos endocanabinoides AEA e 2-AG no comportamento social em diferentes idades 
de desenvolvimento em ratos (Manduca et al., 2015). A utilização de um inibidor das enzimas de degradação de AEA e 2-AG aumentou 0 comportamento social tanto em ratos adolescentes como em adultos. Este efeito foi antagonizado pela administração do antagonista SR 141716A (da mesma família do AM 251) e foi associado a um aumento dos níveis cerebrais de 2-AG, mas não de AEA. Ademais, já foram estabelecidas alterações no sistema endocanabinoide para o modelo animal de autismo por exposição ao ácido valproico. Entre as alterações detectadas foram identificadas a expressão reduzida da enzima diacilglicerol-lipase (DAGL) que sintetiza o 2-AG no cerebelo e aumento da atividade da enzima monoacilglicerol-lipase (MAGL), que cataboliza o 2-AG. Essas alterações foram acompanhadas de mudanças comportamentais tais como a redução da sociabilidade e aumento dos comportamentos relacionados à ansiedade (Kerr et al., 2013).

Um dos objetivos deste primeiro estudo foi determinar a dose para ser utilizada no segundo estudo. A dose determinada foi a de $3,0 \mathrm{mg} / \mathrm{kg}$, e ainda que não tenha sido observada diferença estatística significativa entre esta e o veículo, foi a que aparentemente surtiu maior efeito nos cinco animais testados, apresentando inclusive uma diferença em relação à dose $1,0 \mathrm{mg} / \mathrm{kg}$. Considerando que o número de sujeitos neste estudo foi pequeno $(n=5)$, é possível que esse tenha sido um fator limitante para avaliação do efeito da droga.

Em relação às doses de AM 251 utilizadas neste primeiro estudo, a escolha foi baseada em estudos com primatas da espécie Callithrix penicillata (Cagni \& Barros, 2013) e Macaca mulatta (Schindler et al., 2010), que utilizaram doses de 2,0 mg/kg e 1,0 mg/kg, respectivamente, e com roedores (Rodgers et al., 2005; Delatte \& Paronis, 2008). Entretanto, não há relatos na literatura da administração dessa droga em macacos-prego. Ademais, até o momento, este é o primeiro estudo que avaliou os comportamentos sociais de indivíduos do gênero Sapajus após a utilização de um antagonista do sistema endocanabinoide.

Em nosso estudo, os comportamentos de locomoção e vigilância não foram alterados, ao passo que comportamentos autodirigidos parecem aumentar com a administração do AM 251 na dose de $3,0 \mathrm{mg} / \mathrm{kg}$. O oposto ocorre para os comportamentos sociais. Nesse sentido, o efeito parece ser um 
aumento da atenção autodirigida em detrimento do comportamento social. Manifestações similares são observadas em indivíduos com TEA (Tuchman \& Rapin, 2009). Estes resultados, portanto, corroboram a hipótese de que o SE está envolvido nos déficits sociais observados em pacientes com TEA. 


\subsection{MATERIAIS E MÉTODO - ESTUDO 2 (Avaliação do papel do SE na extinção de memória aversiva em macacos-prego.)}

\subsection{Considerações éticas}

Este estudo foi avaliado e aprovado pela Comissão de Ética no Uso Animal (CEUA) do Instituto de Ciências Biológicas da Universidade de Brasília (UnBDoC no 46060/2014) (Anexo I e II). As diretrizes do Conselho Nacional do Controle de Experimentação Animal (CONCEA) e a Lei Federal oㅜ 11.794/08 (Lei Arouca) também foram seguidas neste estudo.

\subsection{Sujeitos}

Foram utilizados dez macacos-prego adultos, sendo cinco machos e cinco fêmeas. Tais animais foram mantidos em viveiros de $4 \mathrm{~m}$ de comprimento $\times 2,5 \mathrm{~m}$ de largura $\times 3 \mathrm{~m}$ de altura, sob as mesmas condições descritas no tópico 3.3, vivendo em pares ou tríades. Alguns dos machos que participaram deste estudo foram também utilizados no Estudo 1, no entanto houve um intervalo de aproximadamente nove meses entre os experimentos. Dos dez sujeitos incialmente empregados, dois não completaram todas as etapas do procedimento e portanto foram excluídos da análise. Os demais sujeitos foram divididos em dois grupos experimentais: controle e AM 251 ( $n=4)$.

\subsection{Compostos}

Foi utilizado o mesmo antagonista do Experimento 1, o AM 251. Baseado nos resultados do estudo 1 a dose escolhida foi a de $3,0 \mathrm{mg} / \mathrm{kg}$, i.m. A preparação e manutenção foi realizada da mesma forma descrita no tópico 3.4.

\subsection{Viveiro de testes}

As sessões experimentais ocorreram em um viveiro de testes de dimensões de 2,50m de comprimento $\times 1,70 \mathrm{~m}$ de largura $\times 2,15 \mathrm{~m}$ de altura (Figura 10). Este viveiro situava-se no mesmo pavilhão dos viveiros de moradia 
dos sujeitos. No topo desse viveiro, foi colocada uma "caixa-surpresa" $60 \mathrm{~cm}$ de comprimento $\times 70 \mathrm{~cm}$ de largura $\times 30 \mathrm{~cm}$ de altura) presa junto a sua grade de arame (Figura 10B). A caixa (Figura 11) consistiu em paredes opacas de madeira em todos os lados exceto a face em contato com a grade, para permitir a observação do comportamento dos sujeitos quando estes se encontravam dentro dela. Além disso, foi colocada uma parede de madeira de $45 \mathrm{~cm}$ removível em sua parte interna (Figura 11D) de forma que o sujeito precisava entrar completamente na caixa para acessar o seu conteúdo, não sendo possível vê-lo do lado de fora. Esta "caixa-surpresa" apresentava uma abertura circular de $15 \mathrm{~cm}$ de diâmetro, que permitia a entrada dos animais (Figura 11C). $\mathrm{Na}$ abertura, foi colocada uma placa de metal, que funcionou como uma porta, de modo que a caixa poderia ser aberta e fechada (Figura 11B). No compartimento interno da "caixa-supresa", havia uma caixa de acrílico transparente fixa (Figura 11E), que ficava fechada com auxílio de uma trava (Figura 11F).
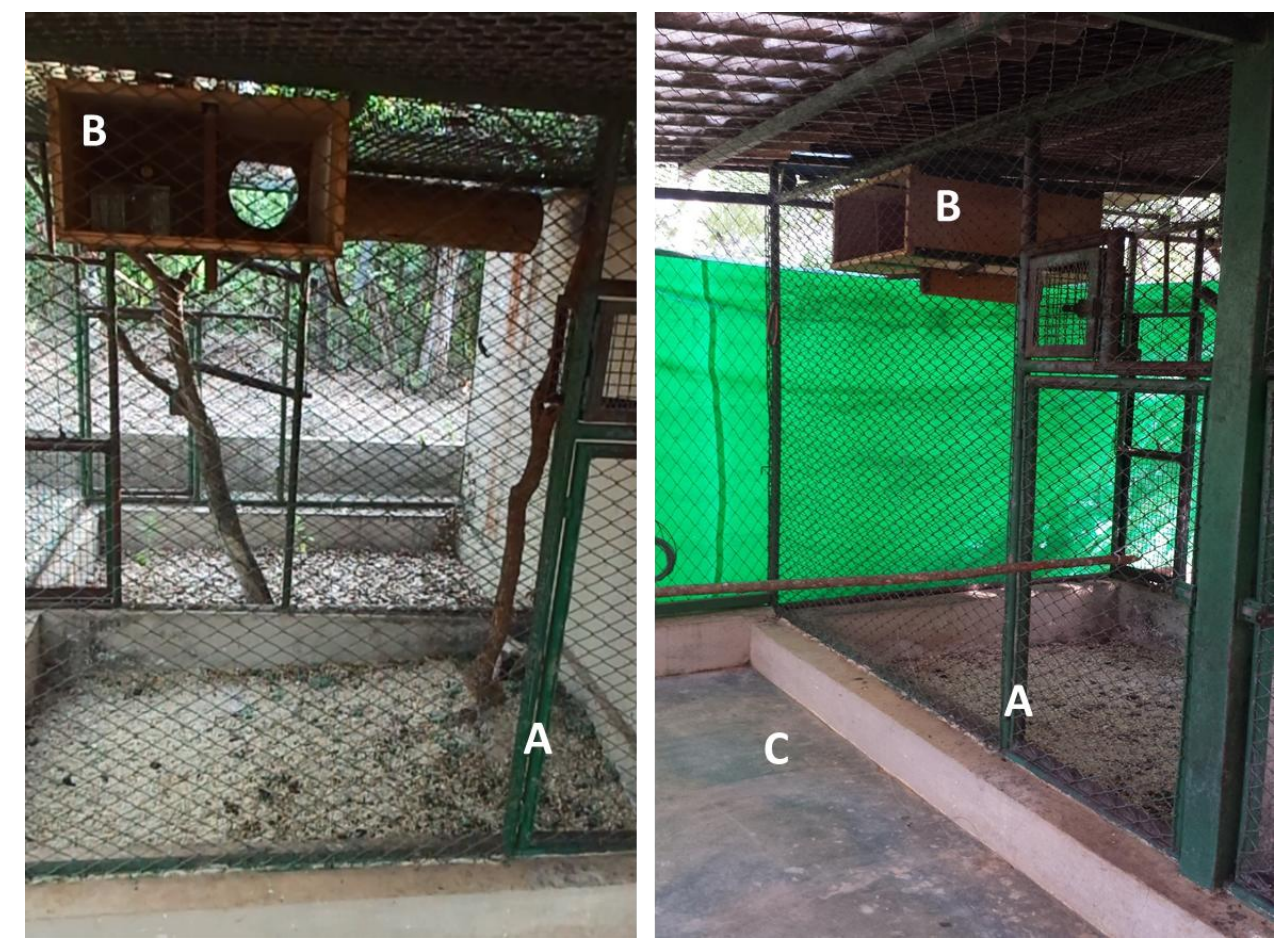

Figura 10. Viveiro de testes. Vista frontal (à esquerda) e vista lateral (à direita). (A) Entrada para o viveiro. (B) "Caixa-surpresa". (C) Corredor de segurança. Fotos: Natália Gonczarowska 


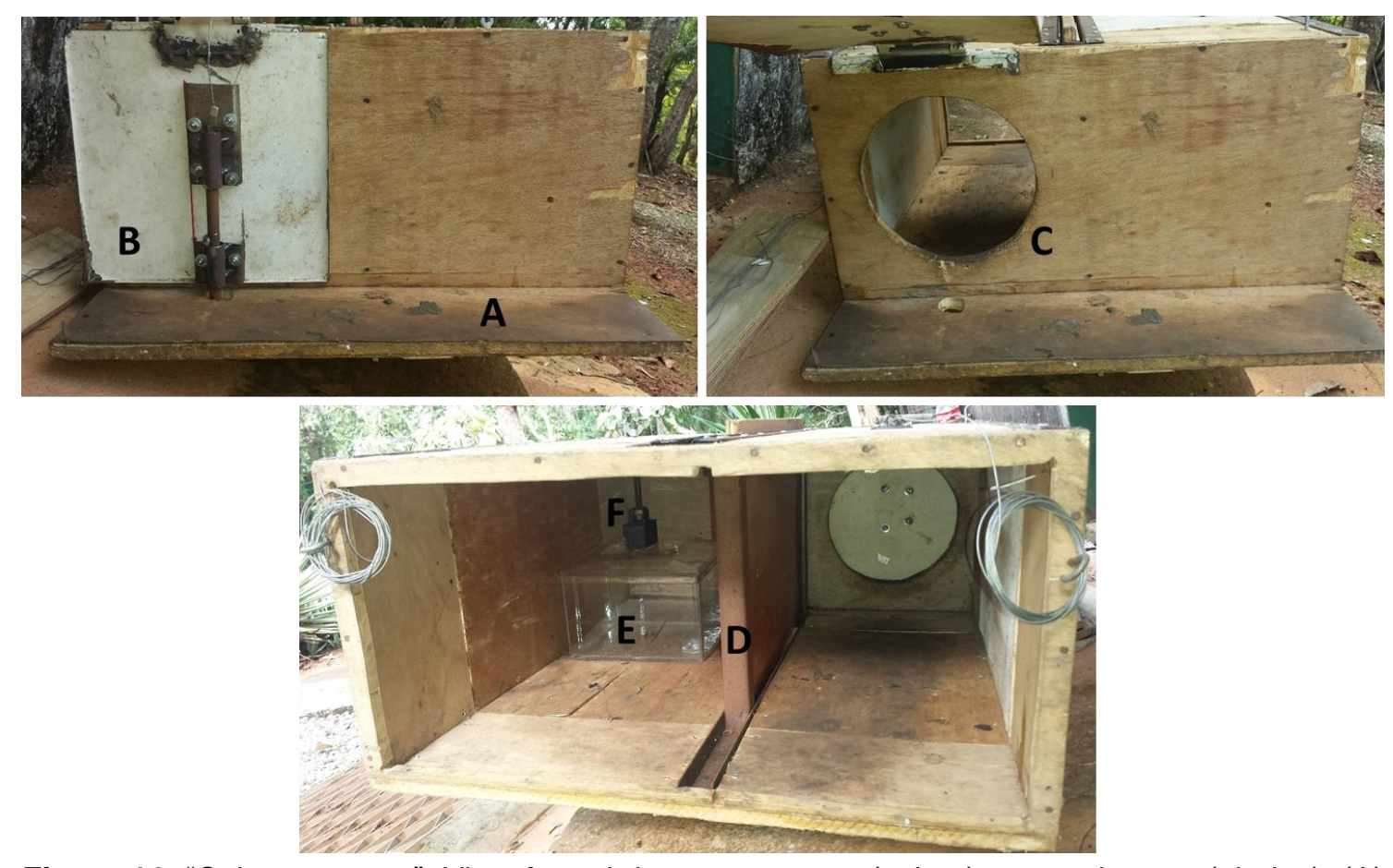

Figura 11. "Caixa-surpresa". Vista frontal da parte externa (acima) e parte interna (abaixo). (A) Suporte para apoio dos animais. (B) Porta de metal. (C) Entrada da caixa. (D) Parede removível. (E) Caixa de acrílico. (F) Trava da caixa de acrílico.

\subsection{Procedimento experimental}

O experimento foi realizado no período matutino, no horário de $8 \mathrm{~h}$ às 10h, entre 12 de outubro a 02 de dezembro de 2015. Houve privação natural (noturna) de alimento durante aproximadamente $12 \mathrm{~h}$, anteriores a cada sessão experimental. Para dar início às sessões, cada animal era individualmente encaminhado de seu viveiro de moradia ao viveiro de testes. Com exceção da etapa de confronto, não houve captura dos sujeitos para se iniciar cada sessão. O início da sessão dava-se quando o animal entrava no viveiro de testes. Cada sessão teve duração de cinco minutos e foi realizada uma sessão por dia para cada animal. Todas as sessões foram gravadas por uma câmera digital (Sony Cyber-shot DSC-W730) e analisadas posteriormente.

O experimento foi dividido em três etapas consecutivas: Habituação, Confronto e Extinção.

$\mathrm{Na}$ Habituação colocou-se uma fruta (uva) dentro da "caixa-surpresa", em cima da caixa de acrílico. Esta etapa tinha como objetivos a adaptação dos sujeitos ao protocolo experimental e a aprendizagem em encontrar alimento na 
"caixa-surpresa". Dessa forma, nesta etapa os animais passaram por um período de adaptação às configurações do teste, como o encaminhamento ao viveiro de testes, à presença dos experimentadores e ao próprio viveiro de testes. Além disso, eles tinham acesso livre à caixa e à fruta dentro dela. $\mathrm{O}$ número de sessões dessa etapa variou de acordo com os indivíduos, apresentando uma média de 21 sessões.

Após a Habituação deu-se início à etapa do Confronto. Esta etapa consistiu de uma única sessão, de cinco minutos, para cada sujeito, e teve como objetivo condicionar aversivamente o animal à "caixa-surpresa". Para isso, foi colocada dentro da caixa de acrílico transparente uma serpente viva, da espécie Epicrates cenchria, conhecida popularmente como jiboia arco-íris (Figura 12). Esta é uma serpente não-peçonhenta, encontrada na América Central e América do Sul (Passos \& Fernandes, 2008). A caixa de acrílico foi colocada dentro da "caixa-surpresa" (ver fig. 11E) e trancada (ver fig. 11F), impossibilitando a saída da jiboia. Para essa etapa de confronto os animais foram divididos em dois grupos: controle e AM 251. A divisão dos animais para cada grupo foi feita de forma pseudoaleatória. Cada sujeito do grupo controle ( $n=4,2$ machos e 2 fêmeas) recebeu uma solução veículo trinta minutos antes da sessão experimental, ao passo que no grupo AM 251 ( $n=4,2$ machos e 2 fêmeas) foi administrada uma solução de AM 251 na dose de $3,0 \mathrm{mg} / \mathrm{kg}$, i.m., também trinta minutos antes do início da sessão. A sessão era iniciada com a entrada do animal no viveiro de testes. Quando o sujeito entrava na "caixasurpresa" a porta de metal fechava a entrada da caixa (ver fig. 11B) e a parede era removida. O sujeito era então mantido por cinco segundos próximo à serpente. Após este breve período de exposição, o animal era liberado da "caixa-surpresa" e era mantido no viveiro de testes até transcorridos os cinco minutos de sessão. 


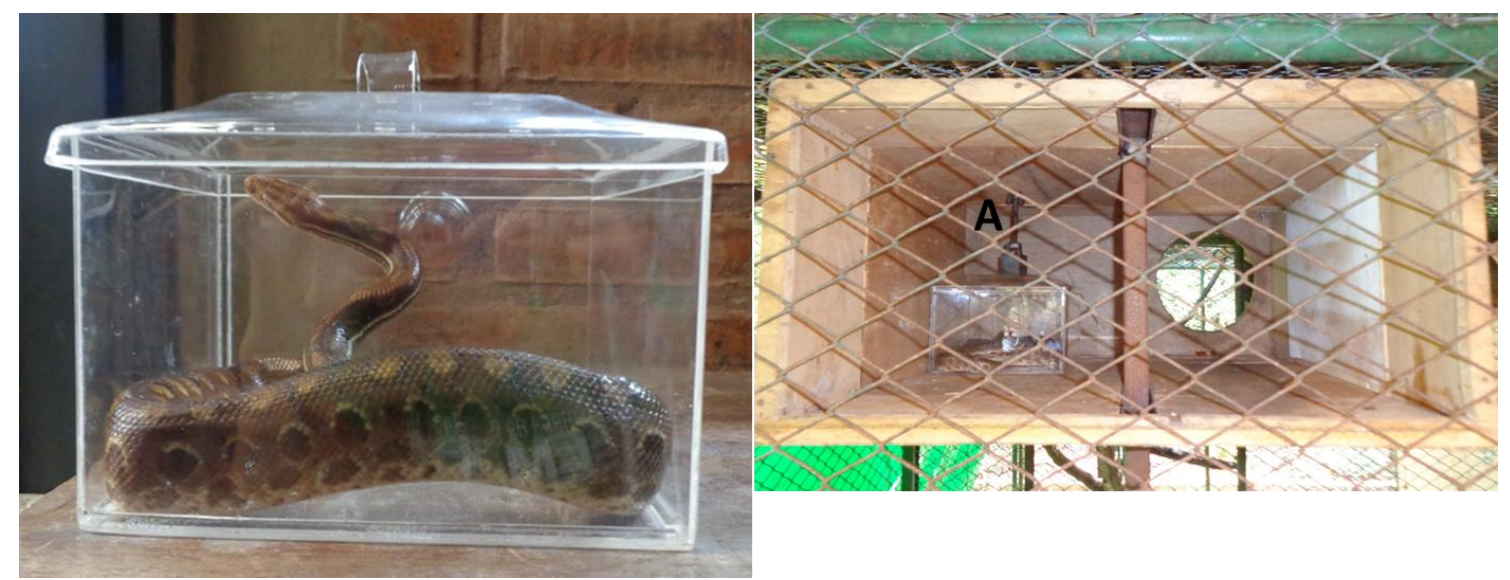

Figura 12. Etapa Confronto. A serpente Epicrates cenchria foi colocada na caixa de acrílico. (A) Trava de segurança.

Após o Confronto, deu-se início à etapa Extinção. Nesta etapa, o procedimento experimental foi idêntico à Habituação. A serpente foi retirada da caixa de acrílico, a fruta foi colocada dentro da "caixa-surpresa" e foi medida a latência de retorno dos animais à esta caixa. As sessões também tiveram duração de cinco minutos e foi realizada uma sessão por dia, por cinco dias, para todos os animais.

\subsection{Análise de dados}

Assim como no estudo 1, este experimento também foi registrado e analisado com o auxílio da câmera de vídeo. Cada sessão teve a duração de 5 minutos (300 segundos) - tempo em que foi analisada a latência de entrada na "caixa-surpresa". No caso do sujeito não entrar na caixa-supresa durante toda sessão, atribuiu-se o tempo de latência máxima de 300 segundos.

Para análise estatística foi realizado primeiramente o teste Shapiro-Wilk, a fim de verificar a normalidade das amostras. Constatadas as amostras como não-paramétricas foram utilizados os testes de Friedman e Wilcoxon para verificar diferenças entre as etapas dentro do mesmo grupo. Para verificar se havia diferença significativa da latência de entrada na caixa entre os dois grupos (controle e AM 251), foi utilizado o teste estatístico de Mann-Whitney $U$.

Para todos os testes estatísticos realizados o nível de significância foi estabelecido em $p \leq 0,05$. 


\subsection{RESULTADOS - ESTUDO 2}

Neste segundo estudo, foi analisada a latência de entrada dos animais na "caixa-surpresa" em todas as etapas do experimento. A Figura 13 apresenta os resultados dos dois grupos experimentais em cada etapa. Observou-se um aumento na latência de entrada na caixa após a etapa do Confronto para os dois grupos. No entanto, esse aumento não foi estatisticamente significativo. Para o grupo controle, a latência de entrada nos dias de Extinção 1, 2 e 4 alcançou o valor de $p=0,068(Z=-, 1826)$ em relação à latência da Habituação. Comparando a etapa do Confronto com os cinco dias de Extinção, foi obtido o valor de $p=0,066$ ( $Z=-1,841$, Confronto $x$ Extinção 1, Confronto $x$ Extinção 4) e $p=0,068(Z=-1,826)$ entre o Confronto $x$ Extinção 2, Confronto $x$ Extinção $3 \mathrm{e}$ Confronto $x$ Extinção 5. Já no grupo AM 251 o valor de $p$ foi de 0,068 ( $Z=-$ $1,826)$ entre os três primeiros dias de Extinção e Habituação, e entre Confronto $x$ Extinção 1, Extinção 3, Extinção 4 e Extinção 5. Não foi encontrada diferença significativa entre a etapa da Habituação e Confronto para os dois grupos experimentais.

Para comparação dos dois grupos foi utilizado o teste estatístico de Mann-Whitney U. Não houve diferença significativa para a latência de entrada na caixa nos dias de Extinção entre o grupo controle e AM 251. Com o passar das sessões observou-se um declínio no tempo de latência de entrada na caixa. Também não foi observada diferença entre os grupos para as outras etapas(Figura13).

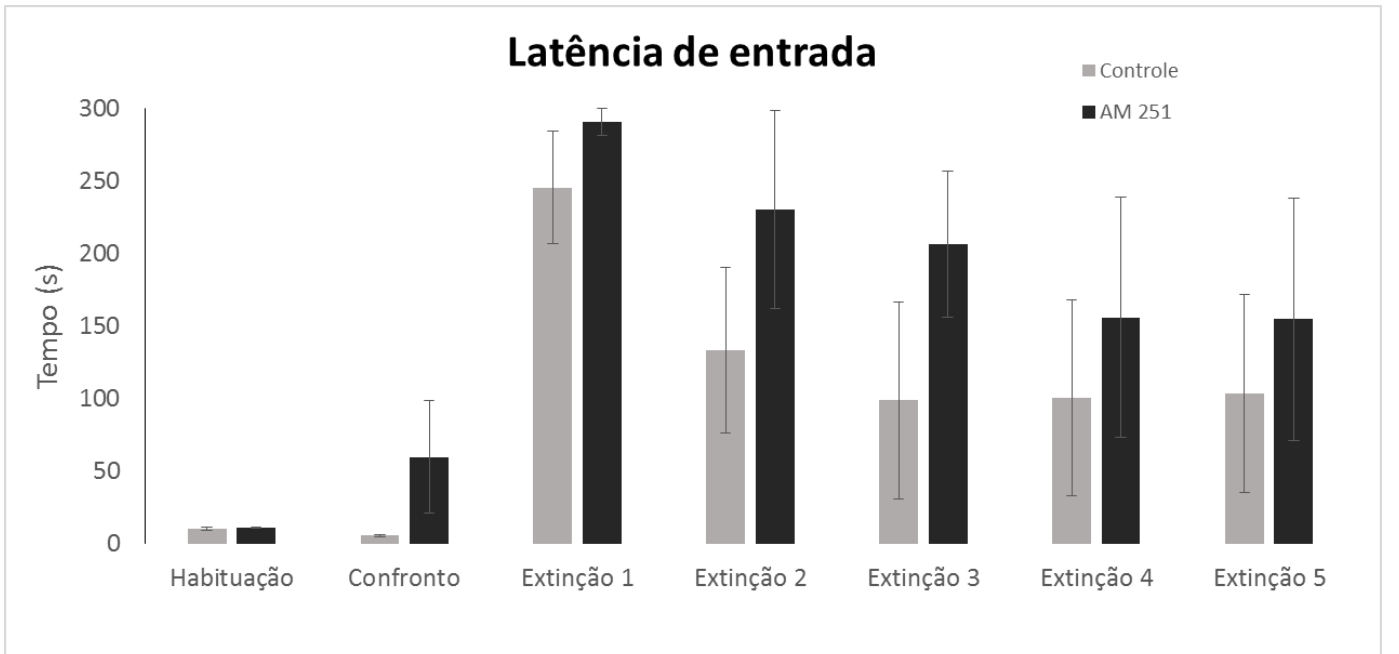

Figura 13. Média do tempo de latência de entrada na caixa ( \pm E.P.M) em todas as etapas experimentais, em segundos. Colunas cinzas representam o grupo controle $(n=4)$, colunas pretas representam o grupo AM $251(n=4)$. 


\subsection{DISCUSSÃO - ESTUDO 2}

O protocolo utilizado em nosso trabalho foi adaptado do estudo de Maior e colaboradores (2011a). Nesse estudo foi utilizado um modelo de serpente de borracha, que se mostrou eficaz na indução de alterações comportamentais indicativas de medo e ansiedade. Outros trabalhos demonstraram a importância de serpentes como estímulos aversivos para primatas nãohumanos, indicando um aumento de respostas de medo na presença de serpentes (Vitale et al., 1991; Barros et al., 2002; Weiss et al., 2015). Isso acontece, pois estes animais são ameaças naturais e representam grande perigo para primatas (Ferrari \& Beltrão-Mendes, 2011; Quintino \& BiccaMarques, 2013; McGrew, 2015).

Vários trabalhos demonstraram a capacidade de estímulos visuais de serpentes em capturar a atenção e induzir respostas de medo em primatas (para revisão, ver Ohman e Mineka, 2003). Nesse sentido, Isbell (2006) sugeriu que serpentes, especialmente as peçonhentas, podem ter sido fundamentais na evolução do sistema visual de primatas. Além disso, sabe-se que a evolução da via visual subcortical coincide com a pressão seletiva de serpentes peçonhentas em primatas do Novo e do Velho mundo (Isbell, 2006). Dados recentes corroboram esta abordagem demonstrando que a lesão de estruturas subcorticais levam à diminuição de respostas a serpentes (Maior et al., 2011a). Um estudo recente demonstrou que neurônios no núcleo pulvinar de macacos japoneses (Macaca fuscata) ingênuos eram mais sensíveis a imagens de serpentes do que a outros estímulos (Le et al., 2013). Dessa forma, o uso de serpentes como estímulos aversivos para primatas mostra-se bastante eficaz.

Nossos resultados mostram que o confronto com a serpente levou a um aumento da latência de entrada na "caixa-surpresa" para os dois grupos experimentais. Apesar de não alcançarem o índice de significância, ficaram muito próximos, por isso esse protocolo pode ser utilizado como método para avaliação da extinção da memória aversiva em macacos-prego. O número de sujeitos ( $n=4$ para cada grupo testado) pode ter prejudicado o resultado da análise estatística. Foram realizadas cinco sessões de extinção neste estudo. Após o Confronto, observou-se uma diminuição da latência de entrada na "caixa-surpresa" com o passar das sessões, tanto para o grupo controle, 
quanto para o grupo AM 251 (ver fig. 14). No entanto, mesmo na última sessão de extinção a latência foi maior do que a observada na habituação, ainda que não fosse alcançada diferença estatística. Isso sugere que não houve extinção total da memória aversiva. Para isso, seria necessário um número maior de sessões de extinção até que o tempo de latência se igualasse ao da habituação.

Ademais, as sessões foram realizadas em um viveiro desconhecido, não frequentado pelos animais anteriormente. Exposição a novos ambientes pode ser um fator estressante para primatas não-humanos (Johnson et al., 1996; Barros et al., 2004; Matheson et al., 2005; Dufour et al., 2011; Cagni et al., 2012). Apesar de terem sido realizadas sessões de exposição ao novo ambiente anteriormente às sessões experimentais, não se pode afirmar que os sujeitos estavam totalmente habituados a este ambiente. Portanto, procedimentos realizados no próprio viveiro de moradia ou em um viveiro adjacente já conhecido pelos animais pode ser mais apropriado para este tipo de teste em primatas não-humanos.

Nossos resultados não mostraram diferença significativa para a latência de retorno à "caixa-surpresa" após a apresentação da serpente, entre os dois grupos experimentais (controle e AM 251). Esses resultados sugerem que 0 AM 251 não alterou o processo de extinção da memória aversiva nos macacosprego.

Um importante fator a ser considerado é o momento de injeção da droga. Em nosso trabalho, o antagonista do SE foi administrado trinta minutos antes da sessão de aquisição da memória aversiva, ou seja, do confronto com a serpente. Estudos com roedores evidenciam que, em geral, endocanabinoides atuam como ansiolíticos endógenos (Navarro, 1997; Martin et al., 2002; Haller et al., 2004; Bortolato et al., 2006; Patel \& Hillard, 2006). Tais resultados sugerem que deficiências no sistema endocanabinoide aumentam a aquisição da memória e, consequentemente, prejudicam a sua extinção. Em concordância com isso, o estudo de Takahashi e colaboradores (2005) mostrou que o antagonismo de CB1 pelo SR 141716A facilita a aquisição e consolidação da memória de camundongos no teste do labirinto em cruz elevado. Além disso, Reich e colaboradores (2008) administraram AM 251 (5,0 mg/kg, i.p.) em camundongos em diferentes estágios da memória e 
observaram um aumento do comportamento de freezing na aquisição. Em contrapartida, há estudos que apontam ausência de efeito de antagonistas do SE na aquisição da memória. (Arenos et al., 2006; Abush \& Akirav, 2010; Simone et al., 2014). No entanto, o efeito de ligantes do SE, aplicados antes das sessões de extinção da memória aversiva, parece ser bem estabelecido. Agonistas do SE facilitam essa extinção, ao passo que antagonistas a dificultam (Reich et al., 2008; Pamplona et al., 2008; Lin et al., 2009; Laricchiuta et al., 2013; Sachser et al., 2015). Dessa forma, com base em nossos resultados e em estudos prévios com roedores, sugere-se que em estudos futuros a droga seja administrada antes das sessões de extinção da memória aversiva. 


\subsection{CONCLUSÕES}

Este trabalho foi o primeiro a avaliar o efeito do bloqueio do receptor CB1 do SE pelo seu antagonista AM 251 na interação social e extinção de memória aversiva em macacos-prego (Sapajus spp). Os resultados do Estudo 1 permitiram concluir que o receptor CB1 pode participar da modulação de comportamentos sociais. Já no Estudo 2 não foi possível observar o papel deste receptor na extinção da memória aversiva dos sujeitos. No entanto, o protocolo utilizado pode ser eficaz para avaliação deste tipo de estudo em macacos-prego. Trabalhos futuros podem aprimorar esta técnica, realizando as sessões em um viveiro conhecido dos animais e aplicando a droga nas sessões de extinção da memória.

Considerando isso, alterações no funcionamento do receptor CB1 do Sistema Endocanabinoide podem estar envolvidas em psicopatologias com sintomas de déficits sociais, como os Transtornos do Espectro do Autismo. Ademais, é possível modular esse receptor a partir do uso de um antagonista do SE, em macacos-prego. Sendo assim, a modulação do receptor CB1 pode ser um alvo farmacológico promissor no tratamento de características comportamentais associadas aos TEA. 


\section{REFERÊNCIAS BIBLIOGRÁFICAS}

Abel EL. Marihuana: The First Twelve Thousand Years. New York: Plenum Press. 1980

Abush H, Akirav I. Cannabinoids modulate hippocampal memory and plasticity. Hippocampus 20: $1126-1138,2010$.

Aggleton JP, Saunders RC. The amygdala - what's happened in the last decade. In: Aggleton JP (ed.). The amygdala - second edition: Functional analysis Oxford: Oxford University Press. 1 - 30, 2000.

Alfaro JWL, Silva JDSE, Rylands AB. How Different Are Robust and Gracile Capuchin Monkeys? An Argument for the Use of Sapajus and Cebus. American Journal of Primatology 74:273 - 86, 2012.

Altmann J. Observational study of behavior: sampling methods. Behaviour 49:227-267, 1974 .

Alvares LO, Engelke DS, Diehl F, Scheffer-Teixeira R, Haubrich J, Cassini LF, Molina VA, Quillfeldt JA. Stress response recruits the hippocampal endocannabinoid system for the modulation of fear memory. Learning \& Memory 17: $202-209,2010$.

Amaral DG, Price JL, Pitkanen A, Carmichael ST. Anatomical organization of the primate amygdaloid complex. In: AggletonJP (ed.). The amygdala: Neurobiological aspects of emotion, child's social environment or the environment pro- memory, and memory dysfunction. New York: John Wiley \& Sons, Inc. 1 - 66, 1992.

Arenos JD, Musty RE, Bucci DJ. Blockade of endocannabinoid CB1 receptors alters contextual learning and memory. European Journal of Pharmacology. 539: 177-183, 2006. 
Arnone M, Maruani J, Chaperon F, Thiebot MH, Poncelet M, Soubrie P, Le Fur G. Selective inhibition of sucrose and ethanol intake by SR 141716, an antagonist of central cannabinoid (CB1) receptors. Psychopharmacology 132(1): $104-106,1997$.

Bambico FR, Cassano T, Dominguez-Lopez S, Katz N, Walker CD, Piomelli D, Gobbi G . Genetic deletion of fatty acid amide hydrolase alters emotional behavior and serotonergic transmission in the dorsal raphe, prefrontal cortex, and hippocampus. Neuropsycopharmacology 35:2083-2100, 2010.

Bari M, Battista N, Fezza F, Gasperi V, Maccarrone M. New insights into endocannabinoid degradation and its therapeutic potential. Mini Reviews in Medicinal Chemistry 6(3): 257 - 268, 2006.

Barros M, Boere V, Mello EL, Tomaz C. Reactions to potential predators in captive-born marmosets (Callithrix penicillata). International Journal of Primatology 23: 443 - 454, 2002.

Barros M, Alencar C, Tomaz C. Differences in aerial and terrestrial visual scanning in captive black tufted-ear marmosets (Callithrix penicillata) exposed to a novel environment. Folia Primatologica 75(2): 85 - 92, 2004.

Betancur C. Etiological heterogeneity in autism spectrum disorders: more than 100 genetic and genomic disorders and still counting. Brain Research 1380:4277, 2011.

Boinski S, Swing SP, Gross TS, Davis JK. Environmental enrichment of brown capuchins (Cebus apella): behavioral and plasma and fecal cortisol measures of effectiveness. American Journal of Primatology 48: 49 - 68, 1999.

Bontrop RE. Non-human primates: essential partners in biomedical research. Immunological Reviews 183:5 - 9, 2001. 
Bortolato M, Campolongo P, Mangieri RA, Scattoni ML, Frau R, Trezza V, La Rana G, Russo R, Calignano A, Gessa GL, Cuomo V, Piomelli D. Anxiolytic-like properties of the anandamide transport inhibitor AM404. Neuropsychopharmacology 31(12): 2652-2659, 2006.

Breibogel CS, Sim-Selley LJ. Basic neuroanatomy and neuropharmacology of cannabinoids. International review of Psyquiatry 21(2): 113-121, 2009.

Buxbaum JD. Multiple rare variants in the etiology of autism spectrum disorders. Dialogues in Clinical Neuroscience 11:35-43, 2009.

Cagni P, Barros M. Cannabinoid type 1 receptor ligands WIN 55,212-2 and AM 251 alter anxiety-like behaviors of marmoset monkeys in an open-field test. Behavioural Brain Research 240: 91 - 94, 2012.

Cagni P, Melo GC, de Jesus AGL, Barros M. Cannabinoid type-1 receptor ligands, alone or in combination with cocaine, affect vigilance-related behaviors of marmoset monkeys. Brain Research 1550: 27 - 35, 2014.

Calignano A, La Rana G, Giuffrida A, Piomelli D. Control of pain initiation by endogenous cannabinoids. Nature 394: 277-281, 1998.

Canale GR, de Freitas MA, Andrade LL. Predation of lizards by a criticallyendangered primate (Sapajus xanthosternos) in a tropical biodiversity hotspot in Brazil. Herpetology Notes. 6:323 - 6, 2013.

CDC. Prevalence of autism spectrum disorders-Autism and Developmental Disabilities Monitoring Network, 14 sites, United States, 2008. MMWR 61(No. SS03):1-19. 2012.

Chapman CA, Fedigan LM. Dietary differences between neighboring Cebus capucinus groups: local traditions, food availability or responses to food profitability? Folia Primatologica. 54:177 - 86, 1990. 
Chevaleyre V, Takahashi KA, Castillo PE. Endocannabinoid-mediated synaptic plasticity in the CNS. Annual Review of Neuroscience 29:37-76, 2006.

Childers SR, Breivogel CS. Cannabis and endogenous cannabinoid systems. Drug and Alcohol Dependence 51: 173-187, 1998.

Colombo G, Agabio R, Diaz G, Lobina C, Reali R, Gessa GL. Appetite suppression and weight loss after the cannabinoid antagonist SR 141716. Life sciences 63(8): 113-117, 1998.

Costa JLGP, Maia LO, Orlandi-Mattos P, Villares JC, Esteves MAF. Neurobiologia da Cannabis: do sistema endocanabinoide aos transtornos por uso de Cannabis. Revisão de Literatura. Jornal Brasileiro de Psiquiatria 60(2): 111-122, 2011.

Delatte MS, Paronis CA. Evaluation of cannabinoid agonists using punished responding and midazolam discrimination procedures in squirrel monkeys. Psychopharmacology. 198: 521 - 528, 2008.

De Fonseca FR, Del Arco I, Bermudez-Silva FJ, Bilbao A, Cippitelli A, Navarro $M$. The endocannabinoid system: physiology and pharmacology. Alcohol and Alcoholism 40(1): 2 - 14, 2005.

De Petrocellis L, Di Marzo V. An introduction to the endocannabinoid system: from the early to the latest concepts. Best Practice and Research. Clinical Endocrinology and Metabolism 23 (1): 1 - 15, 2009.

Devane WA, Hanus L, Breuer A, Pertwee RG, Stevenson LA, Griffin G, Gibson $D$, Mandelbaum A, Etinger A, Mechoulam R. Isolation and structure of a brain constituent that binds to the cannabinoid receptor. Science 258: 1946-1949, 1992.

Di Marzo V, Matias I. Endocannabinoid control of food intake and energy balance. Nature Neuroscience 8: 585 - 589, 2005. 
Di Marzo V. The endocannabinoid system: its general strategy of action, tools for its pharmacological manipulation and potential therapeutic exploitation. Pharmacological research 60: 77 - 84, 2009.

Dubreucq S, Kambire S, Conforzi M, Metna-laurent M, Cannich A, Soria-Gomez E, Richard E, Marsicano G, Chaouloff F. Cannabinoid type 1 receptors located on single-minded 1-expressing neurons control emotional behaviors. Neuroscience 204: 230-244, 2012.

Dufour V, Sueur C, Whiten A, Buchanan-Smith HM. The impact of moving to a novel environment on social networks, activity and wellbeing in two new world primates. American Journal of Primatology 73(8): 802 - 811, 2011.

Elphick MR, Egertova M. The neurobiology and evolution of cannabinoid signalling. Philosophical Transactions of the Royal Society 356(1407):381-408, 2001.

Escartín-Pérez RE, Cendejas-Trejo NM, Cruz-Martínez AM, GonzálezHernandez B, Mancilla-Díaz JM, Florán-Garduno B. Role of cannabinoid CB1 receptors on macronutrient selection and satiety in rats. Physiology \& Behavior 96: 646 - 650, 2009.

Ferrari SF, Beltrão-Mendes R. Do snakes represent the principal predatory threat to callitrichids? Fatal attack of a viper (Bothrops leucurus) on a common marmoset (Callithrix jacchus) in the Atlantic Forest of the Brazilian Northeast. Primates 52:207-209, 2011.

Fiorenza NG, Rosa J, Izquierdo I, Myskiw JC. Modulation of the extinction of two different fear-motivated tasks in three distinct brain areas. Behavioural Brain Research 232: 210 - 216, 2012. 
Fragaszy, D.M.; Visalberghi, E.; Fedigan, L.M. The complete capuchin: the biology of the genus Cebus. 1a ed. Cambridge: Cambridge University Press, pp. 339, 2004.

Garcia-Gutierrez MS, Manzanares J. Overexpression of CB2 cannabinoid receptors decreased vulnerability to anxiety and impaired anxiolytic action of alprazolam in mice. Journal of Psychopharmacology 25(1): 111-120, 2011.

Godoy-Matos AF, Guedes EP, Souza LL, Valério CM. O sistema endocanabinoide: novo paradigma no tratamento da síndrome metabólica. Arquivos brasileiros de endocrinologia \& Metabologia 50(2): 390 - 399, 2006.

Haller J, Varga B, Ledent C, Barna I, Freund TF. Context-dependent effects of CB1 cannabinoid gene disruption on anxiety-like and social behaviour in mice. European Journal of Neuroscience 19 (7): 1906-12, 2004.

Hazekamp A. Cannabis Review. Leiden, The Netherlands: Leiden University, Department of Plant Metabolomics; 2008.

Herkenham M, Lynn AB, Little MD, Johnson MR, Melvin LS, De Costa BR, Rice KC. Cannabinoid receptor localization in brain. Proceedings of the National Academy of Sciences of the United States of America 87:1932-1936, 1990.

Herkenham M, Lynn AB, De Costa BR, Richfield EK. Neuronal localization of cannabinoid receptors in the basal ganglia of the rat. Brain Research 547:267274, 1991a.

Herkenham M, Lynn AB, Johnson MR. Characterization and localization of cannabinoid receptors in rat brain: a quantitative in vitro autoradiographic study. Journal of Neuroscience 11(2):563-583, 1991b.

Howlett AC, Barth F, Bonner TI, Cabral G, Casellas P, Devane WA, Felder CC, Herkenham M, Mackie K, Martin BR, Mechoulam R, Pertwee RG. International Union of Pharmacology. XXVII. Classification of cannabinoid receptors. Pharmacological Reviews 54(2):161-202, 2002. 
Isbell LA. Snakes as agents of evolutionary change in primate brains. Journal of Human Evolution 51: 1 - 35, 2006.

Izquierdo I, Wyrwicka W, Sierra G., Segundo, J. P. Establishment of a trace reflex during natural sleep of cats. Actual Neurophysiology 6: 277 - 296, 1965.

Izquierdo I, Barcik NR, Brioni JD. Pretest beta-endorphin and epinephrine, but not oxotremorine, reverse retrograde interference of a conditioned emotional response in mice. Pharmacology Biochemistry and Behavior 33(3): 545 - 548, 1989.

Jarbe TUC, Ross T, DiPatrizio NV, Pandarinathan L, Makriyannis A. Effects of the CB1 R agonist WIN-55,212-2 and the CB1 R antagonists SR-141716 and AM-1387: open field examination in rats. Pharmacology Biochemistry and Behaviour 85: 243 - 252, 2006.

Johnson EO, Kamilaris TC, Carter CS, Calogero AE, Gold PW, Chrousos GP. The biobehavioral consequences of psychogenic stress in a small, social primate (Callithrix jacchus jacchus). Biological Psychiatry 40(5): 317 - 337, 1996.

Kano M, Ohno-Shosaku T, Hashimotodani Y, Uchigashima M, Watanabe M. Endocannabinoid-mediated control of synaptic transmission. Physiological Reviews 89(1):309-80, 2009.

Kendall D, Stephen A. Behavioral Neurobiology of the Endocannabinoid System. 1a ed. United Kingdom: Springer, 2009.

Kerr DM, Downey L, Conboy M, Finn DP, Roche M. Alterations in the endocannabinoid system in the rat valproic acid model of autism. Behavioral Brain Research 249: 124 - 132, 2013. 
Kim JJ, Fanselow MS. Modality-specific retrograde amnesia of fear. Science 256: 675 - 677, 1992.

Kirkham TC, Williams CM. Endogenous cannabinoids and appetite. Nutrition Research Reviews 14:65-86, 2001.

Kopetz PB, Endowed EDL. Autism worldwide: Prevalence, Perceptions, Acceptance, Action. Journal of Social Sciences 8(2): 196 - 201, 2012.

Laricchiuta D, Centonze D, Petrosini L. Effects of endocannabinoid and endovanilloid systems on aversive memory extinction. Behavioural Brain Research 256: 101 -107, 2013.

Le Foll B, Goldberg SR. Cannabinoid CB1 receptor antagonists as promising new medications for drug dependence. Perspectives in Pharmacology. JPET 312:875-883, 2005.

Le VQ, Isbell LA, Matsumoto J, Nguyen M, Hori E, Maior RS, Tomaz C, Hai Thran A, Ono T, Nishijo H. Pulvinar neurons reveal neurobiological evidence of past selection for rapid detection of snakes. Proceedings of the National Academy of Sciences of the United States of America 110:19000-19005, 2013.

LeDoux JE. The amygdala. Current Biology. 17:R868-R74, 2007.

LeDoux JE. The emotional brain. New York: Simon e Schuster, 1996.

Lent R. Cem bilhões de neurônios? Conceitos fundamentais da neurociência. Atheneu Editora, 848p, 2010.

Lin HC, Mao SC, Su CL, Gean PW. The role of prefrontal cortex CB1 receptors in the modulation of fear memory. Cerebral Cortex 19: 165-175, 2009.

Lisboa SF, Reis DG, Silva AL, Corrêa FMA, Guimarães FS, Resstel LBM. Cannabinoid CB1 receptors in the medial prefrontal cortex modulate the 
expression of contextual fear conditioning. International Journal of Neuropsycopharmacology 13: 1163 - 1173, 2010.

Litvin Y, Phan A, Hill MN, Pfaff DW, McEwen BD. CB1 receptor signaling regulates social anxiety and memory. Genes, Brain and Behavior 12: 479-489, 2013.

Loftus EF, Palmer JC. Reconstruction of automobile destruction: An example of interaction between language and memory. Journal of Verbal Learning \& Verbal Behavior 13: 585 - 589, 1974.

Maior RS. Avaliação da via colículo-pulvinar no processamento das emoções e cognição social em primatas não-humanos.Tese (Doutorado em Ciências da Saúde) - Programa de Pós Graduação em Ciências da Saúde, Universidade de Brasília, Brasília, 2011.

Maior RS, Hori E, Barros M, Teixeira DS, Tavares MCH, Ono T, Nishijo H, Tomaz C. Superior colliculus lesions impair threat responsiveness in infant capuchin monkeys. Neuroscience letters 504: 257 - 260, 2011 a.

Maior RS, Barros M, Tomaz C. Contributions of Non-Human Primates to the Understanding of Cocaine Addiction, Psychiatric Disorders - Trends and Developments, Dr. Toru Uehara (Ed.). ISBN: 978-953-307-745-1, InTech, $2011 b$.

Malcher-Lopez R, Ribeiro S. Maconha, Cérebro e Saúde. Rio de Janeiro: Vieira \& Lent, 2007.

Malcher-Lopez R. Canabinoides ajudam a desvendar aspectos etiológicos em comum e trazem esperança para o tratamento de autismo e epilepsia. Revista da Biologia 13(1):43-59, 2014.

Manduca A, Morena M, Campolongo P, Servadio M, Palmery M, Trabace L, Hill MN, Vanderschuren LJMJ, Cuomo V, Trezza V. Distinct roles of the 
endocannabinoids anandamide and 2-arachidonoyglycerol in social behavior and emotionality at different developmental ages in rats. European Neuropsychopharmacology 25: 1362 - 1374, 2015.

Marco EM, Laviola G. The endocannabinoid system in the regulation of emotions throughout lifespan: a discussion on therapeutic perspectives. Journal of Psychopharmacology 26: 150 - 163, 2011.

Maren S. Neurobiology of Pavlovian fear conditioning. Annual Review of Neuroscience 24: 897 - 931, 2001.

Maren S, Quirk GJ. Neuronal signalling of fear memory. Nature Reviews Neuroscience 5: 844-852, 2004.

Markram H, Rinaldi T, Markram K. The intense world syndrome - an alternative hypothesis for autism. Frontiers in Neuroscience 1(1):77-96, 2007.

Markram K, Rinaldi T, La Mendola D, Sandi C, Markram H. Abnormal fear conditioning and amygdala processing in an animal model of autism. Neuropsychopharmacology. 33(4):901-12, 2008.

Martin M, Ledent C, Parmentier M, Maldonado R, Valverde O. Involvement of CB1 cannabinoid receptors in emotional behaviour. Psychopharmacology (Berl) 159: 379-387, 2002.

Matheson MD, Fragaszy DM, Johnson-Pynn JS. Response to novel housing in two groups of captive tufted capuchin monkeys (Cebus apella). Primates 46(4): $235-240,2005$.

McGrew WC. Snakes as hazards: modelling risk by chasing chimpanzees. Primates 56(2): 107 - 111, 2015. doi:10.1007/s10329-015-0456-4

McLaughlin PJ, Winston K, Swezey L, Wisniecki A, Aberman J, Tardif DJ, Betz AJ, Ishiwari K, Makriyannis A, Salamone JD. The cannabinoid CB1 antagonists 
SR $141716 A$ and AM 251 supress food intake and food-reinforced behavior in a variety of tasks in rats. Behavioural Pharmacology 14(8): 583 - 588, 2003.

Mechoulam R, Hanus L. A historical overview of chemical research on cannabinoids. Chemistry and Physics of Lipids 108(1-2):1-13, 2000.

Morena M, Campolongo P. The endocannabinoid system: an emotional buffer in the modulation of memory function. Neurobiology of Learning and Memory 112: 30 - 43, 2014.

Nader K. Memory traces unbound. Trends in Neuroscience 26(2): 65 - 72, 2003.

Navarro M, Hernandez E, Munoz RM, Del Al, Villanua MA, Carrera MR, Rodriguez DF. Acute administration of the CB1 cannabinoid receptor antagonist SR 141716A induces anxiety-like responses in the rat. Neuroreport 8: 491 496, 1997.

Ohman A, Mineka S. The malicious serpent: snakes as a prototypical stimulus for an evolved module of fear. Current Directions in Psychological Science 12: 5 $-9,2003$.

Ong WY, Mackie K. A light and electron microscopic study of the CB1 cannabinoid receptor in primate brain. Neuroscience 92(4): 1177 - 1191, 1999.

Ossato A, Vigolo A, Trapella C, Seri C, Rimondo C, Serpelloni G, Marti M. JWH-018 impairs sensorimotor functions in mice. Neuroscience 300: $174-$ 1888, 2015.

Pamplona FA, Bitencourt RM, Takahashi RN. Short- and long-term effects of cannabinoids on the extinction of contextual fear memory in rats. Neurobiology of Learning and Memory 90: 290 - 293, 2008. 
Parolaro D, Realini N, Vigano D, Guidali C, Rubino T. The endocannabinoid system and psychiatric disorders. Experimental Neurology 224: 3-14, 2010.

Passos P, Fernandes R. Revision of the Epicrates cenchria Complex (Serpentes: Boidae). Herpetological Monographs 22(1): 1 - 30, 2008.

Patel S, Hillard CJ. Pharmacological evaluation of cannabinoid receptor ligands in a mouse model of anxiety: further evidence for an anxiolytic role for endogenous cannabinoid signaling. Journal of Pharmacology and Experimental Therapeutics 318(1): 304-311, 2006.

Pellis SM, Pellis V. The playful brain: venturing to the limits of neuroscience. Oxford, UK: Oneworld Publications. 2009.

Pertwee RG. Pharmacological actions of cannabinoids. Handb Exp Pharmacol. 168: 1 - 51, 2005.

Pertwee RG. Cannabinoid pharmacology: the first 66 years. British Journal of Pharmacology 147:S136-S171, 2006.

Piomelli D. The molecular logic of endocannabinoid signaling. Nature reviews neuroscience 9: $474-478,2003$.

Polsek D, Jagatic T, Cepanec M, Hof PR, Simic G. Recent developments in neuropathology of autism spectrum disorders. Translational Neuroscience 2(3):256-264, 2011.

Pough $\mathrm{FH}$, Janis $\mathrm{CM}$, Heiser JB. A vida dos vertebrados (4⿳亠丷a edição). Atheneu, São Paulo, p. 750, 2008.

Quintino EP, Bicca-Marques JC. Predation of Alouatta puruensis by Boa constrictor. Primates 54: 325 - 330, 2013. 
Ratano P, Everitt BJ, Milton AL. The CB1 receptor antagonist AM 251 impairs reconsolidation of pavlovian fear memory in the rat basolateral amygdala. Neuropsycopharmacology 39 (11): 2529 - 2537, 2014.

Reich CG, Mohammadi MH, Alger BE. Endocannabinoid modulation of fear responses: learning and state-dependent performance effects. Journal of Psychopharmacology 22(7): 769 - 777, 2008.

Rimpley K, Buchanan-Smith HM. Reliably signalling a startling husbandry event improves welfare of zoo-housed capuchins (Sapajus apella). Applied animal behaviour science 147: $205-213,2013$.

Rinaldi T, Perrodin C, Markram H. Hyper-connectivity and hyper-plasticity in the medial prefrontal cortex in the valproic Acid animal model of autism. Frontiers in Neural Circuits 2:4, 2008.

Rodgers RJ, Evans PM, Murphy A. Anxiogenic profile of AM251, a selective cannabinoid $\mathrm{CB} 1$ receptor antagonist, in plus-maze-naïve and plus-maze experienced mice. Behavioral Pharmacology. 16:405-413, 2005.

Rodrigues RC. Ciclo reprodutivo de macacos-prego (Cebus libidinosus) em cativeiro: aspectos comportamentais e hormonais. Dissertação (Mestrado em Ciências da Saúde) - Programa de Pós Graduação em Ciências da Saúde, Universidade de Brasília, Brasília, 2010.

Rose LM, Fedigan LM. Vigilance in white-faced capuchins, Cebus capucinus, in Costa Rica. Animal Behaviour 49: 63 - 70, 1995.

Sachser RM, Crestani AP, Quillfeldt JA, Souza TME, Alvares LD. The cannabinoid system in the retrosplenial cortex modulates fear memory consolidation, reconsolidation, and extinction. Learning \& Memory 22: $584-$ $588,2015$. 
Saito V, Wotjak C, Moreira F. Exploração farmacológica do sistema endocanabinoide: novas perspectivas para o tratamento de transtornos de ansiedade e depressão? Revista Brasileira de Psiquiatria. 32: Supl I, 2010.

Schindler CW, Panlilio LV, Gilman JP, Justinova Z, Vemuri VK, Makriyannis A, Goldberg SR. Effects of cannabinoid receptor antagonists on maintenance and reinstatement of methamphetamine self-administration in rhesus monkeys. European Journal of Pharmacology 633: 44 - 49, 2010.

Silva GT, Le Bé JV, Riachi I, Rinaldi T, Markram K, Markram H. Enhanced longterm microcircuit plasticity in the valproic Acid animal model of autism. Frontiers in Synaptic Neuroscience 1:1, 2009.

Simone JJ, Green MR, Hodges TE, McCormick CM. Differential effects of CB1 receptor agonism in behavioural tests of unconditioned and conditioned fear in adult male rats. Behavioural Brain Research 279: 9 - 16, 2014.

Sink KS, Segovia KN, Sink J, Randall PA, Collins LE, Correa M, Markus EJ, Vemuri VK, Makriyannis A, Salamone JD. Potential anxiogenic effects of cannabinoid $\mathrm{CB} 1$ receptor antagonists/inverse agonists in rats: Comparisons between AM4113, AM251, and the benzodiazepine inverse agonist FG-7142. European Neuropsychopharmacology 20: 112 - 122, 2009.

Schaefer GB, Mendelsohn NJ. Clinical genetics evaluation in identifying the etiology of autism spectrum disorders: 2013 guideline revisions. Genetics in Medicine 15(5): 399-407, 2013.

Schneider M, Koch M. Deficient social and play behavior in juvenile and adult rats after neonatal cortical lesion: Effects of chronic pubertal cannabinoid treatment. Neuropsychopharmacology 30(5), 944-957, 2005.

Svíženská I, Dubovy P, Sulcova A. Cannabinoid receptors 1 and 2 (CB1 and $\mathrm{CB} 2$ ), their distribution, ligands and functional involvement in nervous system 
structures - a short review. Pharmacology, Biochemistry and Behavior 90: 501$511,2008$.

Takahashi RN, Pamplona FA, Fernandes MS. The cannabinoid antagonist SR141716A facilitates memory acquisition and consolidation in the mouse elevated T-maze. Neuroscience Letters 380: 270 - 275, 2005.

Tomaz C. Amnésia. In: Graeff FG, Brandão ML (eds.). Neurobiologia das doenças mentais. Lemos Editora 175 - 184, 1993.

Tomaz C, Frank JE, Conde C. Integrative function of the amygdala in emotional storage. In: Ono T, Matsumoto G, Llinás RR, Berthoz A, Norgren R, Nishijo H, Tamura R (eds.). Cognition and Emotion in the Brain: Selected topics of the International Symposium on Limbic and Association Cortical Systems. Elsevier. Amsterdã 335 - 346, 2003.

Trezza V, Vanderschuren L. Bidirectional cannabinoid modulation of social behavior in adolescent rats. Psychopharmacology 197: 217-227, 2008.

Trezza V, Baarendse P, Vanderschuren L. The pleasures of play: pharmacological insights into social reward mechanisms. Trends in Pharmacological Sciences 31:463-469, 2010.

Trezza V, Damsteegt R, Manduca A, Petrosino S, Van Kerkhof LWN, Pasterkamp RJ, Zhou YP, Campolongo P, Cuomo V, Di Marzo V, Vanderschuren LJMJ. Endocannabinoids in amygdala and nucleus accumbens mediate social play reward in adolescent rats. Journal of Neuroscience 32(43):14899-14908, 2012.

Tuchman R, Rapin I. Tradução: Denise Regina de Sales. Autismo: uma abordagem neurobiológica. Porto Alegre: Artmed, 376p., 2009.

Tulving E. Multiple memory-systems and consciousness. Human Neurobiology 6(2): $67-80,1987$. 
Vitale AF, Visalberghi E, De Lillo C. Responses to a snake model in captive crab-eating macaques (Macaca fascicularis) and captive tufted capuchins (Cebus apella). International Journal of Primatology 12:277-286, 1991.

Vlachou S, Nomikos GG, Panagis G. WIN 55-212,2 decreases the reinforcing actions of cocaine throught $\mathrm{CB} 1$ cannabinoid receptor stimulation. Behavioural Brain Research 141: 215 - 222, 2003.

Weigel RM. The facial expressions of the brown capuchin monkey (Cebus apella). Behavior 68: $250-276,1978$.

Weiss L, Brandl P, Frynta D. Fear reactions to snakes in naïve mouse lemurs and pig-tailed macaques. Primates 56: 279 - 284, 2015.

Xavier GF. A modularidade da memória. Psicologia USP 4(1-2): 61 - 115, 1993. 


\section{ANEXO I}

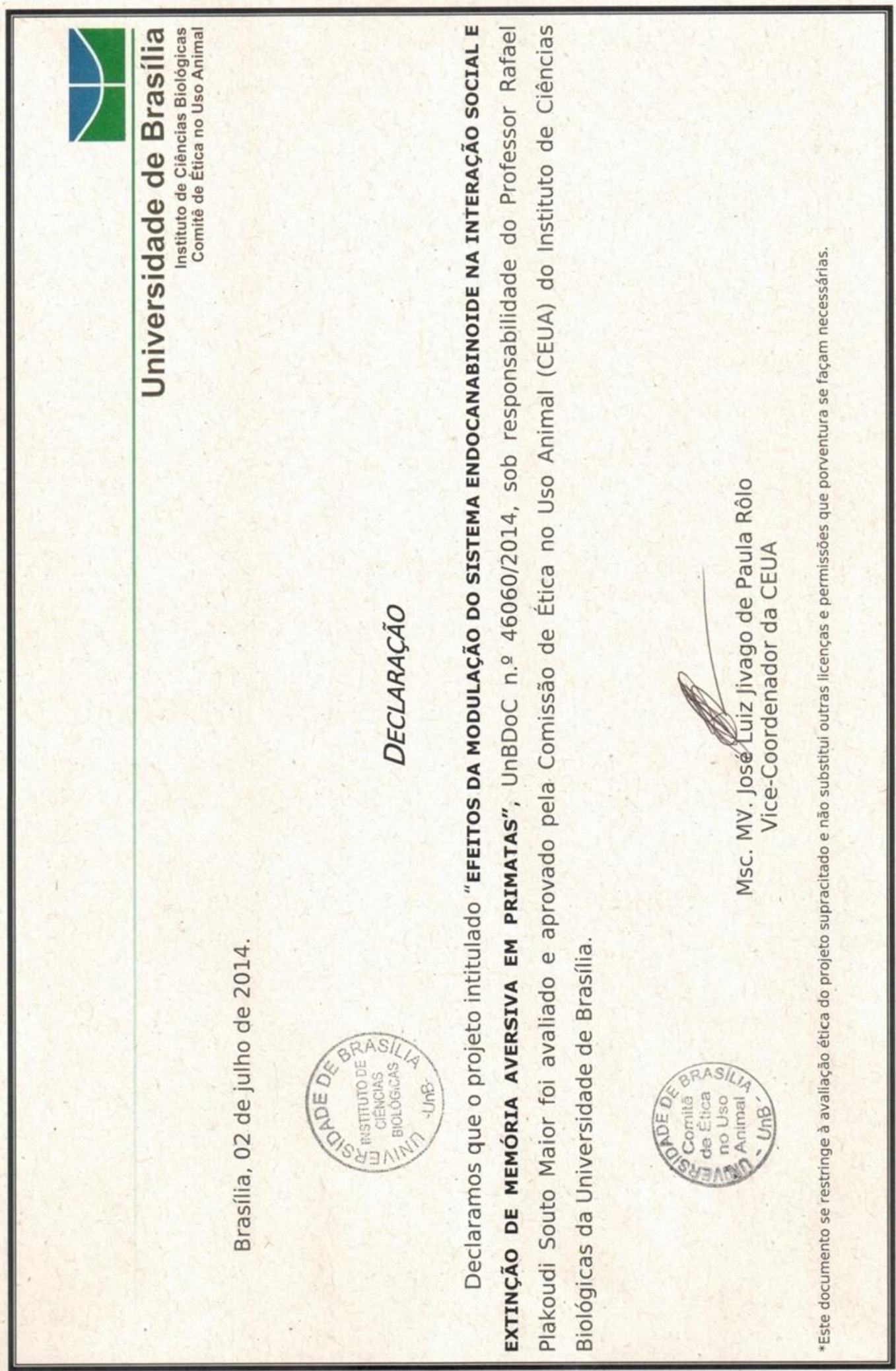


ANEXO II

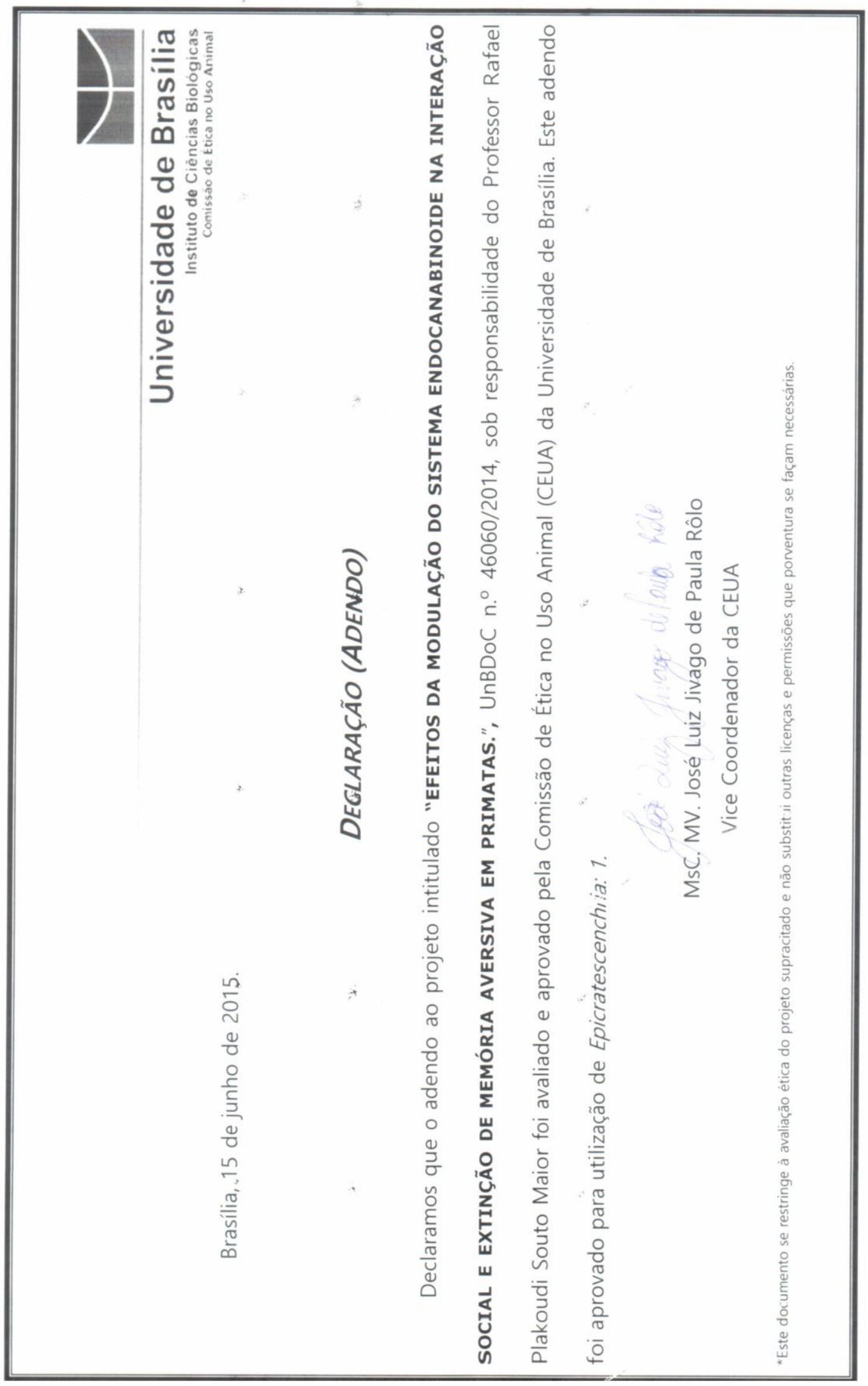

